\title{
IDŐJÁRÁS
}

Quarterly Journal of the Hungarian Meteorological Service

Vol. 125, No. 2, April-June, 2021, pp. 291-319

\section{A hydrological toolkit to delineate patterns of blue and green water in a regional semi-arid climate in Iran via CMIP5 models}

\author{
Amirhosein Aghakhani Afshar ${ }^{1 *}$ and Yousef Hassanzadeh ${ }^{2,3}$ \\ ${ }^{1}$ Department of Water Engineering \\ Faculty of Civil Engineering \\ University of Tabriz, Tabriz, Iran \\ ${ }^{2}$ Department of Water Engineering \\ Center of Excellence in Hydroinformatics, \\ Faculty of Civil Engineering \\ University of Tabriz, Tabriz, Iran. \\ ${ }^{3}$ Farazab Co. (Consulting Engineers), PMO, Tabriz, Iran. \\ *Corresponding authorE-mail: a.h.aghakhani@tabrizu.ac.ir \\ (Manuscript received in final form May 26, 2020)
}

\begin{abstract}
Water scarcity and the climate change impacts on water components will drastically alter everybody's life. The Soil and Water Assessment Tool (SWAT) has been utilized in this study in combination with Sequential Uncertainty Fitting Program (SUFI-2) to simulate precipitation $(\mathrm{P})$, temperature $(\mathrm{T})$, blue water $(\mathrm{BW})$, green water flow $(\mathrm{GWF})$, and green water storage (GWS) in Kashafrood River Basin, Iran. The outputs of two Coupled Model Intercomparison Project Phase 5 (CMIP5) models (MIROC-ESM and GFDL-ESM2G) are selected for hydrological modeling under Representative Concentration Pathways (RCPs) of 4.5 and 8.5 and for the near future (2014-2042) and far future (2043-2100) periods compared to historical period (1995-2011). The results of RCPs, in comparison with the historical period, show that $\mathrm{P}$ and $\mathrm{BW}$ are increased and in GFDL-ESM2G are better than MIROC-ESM, while T tends to increase, and MIROC-ESM is better than GFDL-ESM2G. GWF, in all future periods (except in MIROC-ESM in near future and under RCP4.5 and 8.5) and in all RCPs tend to decrease, and the results of MIROC-ESM are better than those of GFDL-ESM2G in near future and are vice versa in far future. It is anticipated that GWS continues its historical trend in the future.
\end{abstract}

Key-words: SWAT, MIROC-ESM, GFDL-ESM2G, RCPs, blue and green waters 


\section{Introduction}

Climate change largely affects the hydrological cycle and availability of water resources (Pachauri et al., 2014). Its impact is more drastic in arid and semi-arid areas, and its effect on the accessibility of water resources to human has been focused in many studies. Studies show that climate change has an adverse impact on ecosystems and causes water crisis, both in arid and semi-arid areas (Falkenmark and Rockström, 2006), and millions of people would be dealing with the lack of uncontaminated water all over the world (Pereira et al., 2009). A comprehensive review of climate change is a necessary path for understanding and managing the limited freshwater resources in long-term. There is a dire need for climate change impact assessment in the realm of water resources to identify the changes in water usage patterns, especially in arid and semi-arid areas. Climate change is one of the main factors effecting the quantity and quality of water resources in a river basin. Climate models are developed in recent decades by scientists in order to study these effects. General Circulation Models (GCMs) are widely being applied in predicting various scenarios for the climatic change. The Intergovernmental Panel on Climate Change (IPCC) is responsible for gathering and reviewing the world wide climate models in the framework of the international climate change assessment report for policymakers and public users (IPCC, 1990). So far, IPCC has presented five distinct versions of GCM models including: First Assessment Report (FAR), Second Assessment Report (SAR), Third Assessment Report (TAR), Fourth Assessment Report (AR4), and Fifth Assessment Report (AR5) models. The IPCC AR5 has provided a novel approach of developing scenarios. These scenarios extend in the scope of possible radiative forcing scenarios called Representative Concentration Pathways (RCPs), whereas AR4 uses scenarios from the IPCC Special Report on Emissions Scenarios (SRES). The RCPs cover a broader extent of possibilities than the SRES marker scenarios employed in the modeling for the IPCC AR3 and AR4. Some RCPs account for mitigation and adaptation policies in opposition to SRES (see Chapter 9, IPCC, 2013).

The Fifth Assessment Report (AR5) emission scenarios are founded on the different specifications, including technology level, social and economic status, and future policies that can lead to greenhouse gas emission and climate change to four new different paths. Later models were developed due to the concentration of greenhouse gases by considering radiative forcing and higher model resolution (Taylor et al., 2012). The Fifth Phase of the Coupled Model Intercomparison Project (CMIP5) including sixty-one climate change models, relies on the bases of new greenhouse gas concentration emission of RCP (Moss et al., 2010) and has started a few years ago under the international climate change agreement for AR5. CMIP5 has supplied a necessary basis from the compilation of AR5 and coordinated to be used in AR5, and allows for simulating, comparing, and synthesizing widespread hydro-climatic outputs from various GCMs (IPCC, 2013; Taylor et al., 2012). 
Freshwater cycle is classified into two different categories by involving the hydrological process and the storage type: green water $(\mathrm{GW})$ and blue water (BW). The concepts of GW and BW were initially proposed by Falkenmark in 1995 and then expanded by other researchers (Badou et al., 2018; Hoekstra, 2017; Veettil and Mishra, 2016; Zang et al., 2012; Faramarzi et al., 2009; Falkenmark and Rockström, 2006). Basically, human beings use BW as an important source of water availability in daily life. BW is a summation of surface runoff (originated from rivers, lakes, etc.) and groundwater aquifer recharge and used for irrigation purposes. Globally, irrigation water includes almost $70 \%$ of total human BW consumption (about $2500 \mathrm{~km}^{3} /$ year). On the other hand, 90 percent of BW consumption (about 1200 to $1800 \mathrm{~km}^{3} /$ year) belongs to agricultural $\mathrm{BW}$ consumption that transpires via the crops or evaporates from soils, vegetation, leaves, trees, or from water bodies. It is a misconception that agricultural water consumption is largely dependent on BW withdrawals, because about $80 \%$ of global croplands are rainfed, which consume the required water from precipitation that infiltrated into the unsaturated soil or stored in the soil texture (so-called green water, GW) (Mekonnen and Hoekstra, 2016). Food production and global ecosystems mainly depend on GW (a significant water source for terrestrial ecosystems), and an amount of about $5000 \mathrm{~km}^{3} /$ year uses these water components as the only resource that supports rainfed agriculture on a global scale (Lathuillière et al., 2016; Zang et al., 2012; Falkenmark and Rockström, 2006). GW includes green water flow (GWF), which is the actual evapotranspiration of soil, water, and plants released into the atmosphere; and green water storage (GWS), which is the water volume stored in different soil layers at the end of a time period (Cuceloglu et al., 2017; Rodrigues et al., 2014; Falkenmark and Rockström, 2006). Although, BW is essential in irrigation water, but GWF and GWS resources are more than three times as large as BW consumption, and they play an essential role in crop production as well as in the supply of ecosystem services (Falkenmark, 1995). Thus, paying attention to BW and GW is very important in the management of watershed basins. In the past few years, many studies in the world have concentrated on BW and GW in the field of hydrology and water resources under climate change (Pandey et al., 2019; Afshar et al., 2018; Badou et al., 2018; Shrestha et al., 2017; Zang et al., 2012; Faramarzi et al., 2009) and on the importance of these components in different watershed basins for strategic decision-making (Schyns et al., 2019; Veettil and Mishra, 2016; Zang et al., 2012).

Various physically-based integrated distribution models have extended for analysis and management of catchment, including: Hydrologic Simulation Program-Fortran (HSPF), Agricultural Non-Productive Source (AGNPS) model, Erosion Productivity Impact Calculator (EPIC), Hydrology Laboratory-Research Distributed Hydrologic Model (HL-RDHM), Water Erosion Prediction Project (WEPP), Chemical Runoff Erosion from Agricultural Management System (CREAMS), and Soil and Water Assessment Tools (SWAT). SWAT was 
developed and employed in most studies in order to determine the effects of climate change in the quantity and spatiotemporal distribution of BW and GW, and also the impacts of human activity on agricultural yield, chemical, and stream flow in a large scale basin (Pandey et al., 2019; Dadfar et al., 2019; Fazeli Farsani et al., 2019; Masud et al., 2018; Afshar and Hassanzadeh, 2017; Veettil and Mishra, 2016; Besharat et al., 2015; Faramarzi et al., 2009, 2013;). The Calibration and Uncertainty Procedures (SWAT-CUP) computer program, which connects to SWAT model, is applied in order to investigate the sensitivity analysis, the model parameters, and the calibration and validation processes (Hassanzadeh et al., 2019; Shivhare et al., 2018; Afshar et al., 2018; Uniyal et al., 2015; Abbaspour et al., 2007). SWAT-CUP program also contains four algorithms to perform these processes, including a Monte Carlo Markov Chain (MCMC) algorithm, Generalized Likelihood Uncertainty Estimation (GLUE), Parameter Solution (ParaSol), and Sequential Uncertainty Fitting program (SUFI-2). Among them, SUFI-2 has extensively been employed in many parts of the world to optimize the parameters of the SWAT model, and it is found to be quite efficient in large scale models in comparison with another algorithms of SWAT-CUP program (Hassanzadeh et al., 2019; Shivhare et al., 2018; Li et al., 2017; Abbaspour et al., 2007).

Most countries in the Middle East such as Iran are located in arid or semi-arid regions with low precipitation and high temperature. The climate change in Iran, like in other similar climates, is recognized as a challenging subject, and its negative impacts on water resources can also affect the environmental and socio-economic issues, and mainly the agricultural sector. The Kashafrood River Basin (KRB), in the northeast part of Iran with a wide range of climate conditions, is expected to face changes in both water quantity and quality in future time periods. On the other hand, cultivation is carried out in irrigated agricultural (28.56\%) and rainfed (15.55\%) forms in the majority portion of KRB (about $44.11 \%$ of the total land use). Given the strategic importance of KRB as the only water supply of northeast Iran, not much work (except for the research done by Afshar et al. $(2017,2018)$ ) has been done to study the spatial and temporal changes of BW, GWF, and GWS (and even rainfall and temperature) in the basin under future climate change scenarios.

Beyond the abovementioned facts, the current study consists of the following main objectives that are considered as innovation of the article: (1) identification of sensitive parameters of the SWAT model via the Regional Sensitivity Analysis (RSA) method based on the Latin hypercube sampling (LHS) theory and the Kolmogorov-Smirnov (K-S) test, (2) survey, comparison, and discussion the spatial and temporal variations of water resources components (e.g., blue water, green water flow, and green water storage) in the KRB during a period of 106 years by using MIROC-ESM and GFDL-ESM2G models of CMIP5 under two RCPs (4.5 and 8.5). In addition, we explain the way that the water resources components have changed in the basin levels over three time periods from 1995 to 2100 (historical: 1995-2011, near future: 2014-2042, and far future: 2043-2100). The impact of 
climate parameters, such as the influence of precipitation and temperature on the availability of water resources in the basin, has also been investigated, so the third main objective of this study is the investigation of hydro-climatic conditions in sub-basins that contain hydraulic structures such as dams' reservoirs (Torogh and Kardeh dams) in them by MIROC-ESM and GFDL-ESM2G models and two RCPs (4.5 and 8.5).

\section{Materials and methods}

\subsection{Study area}

The Kashafrood River Basin, KRB is located in the northeastern part of Iran with an area of 16870 square kilometers, which is the largest basin in the Khorasan Razavi Province and located between latitudes of $35^{\circ} 35^{\prime}$ to $37^{\circ} 07^{\prime} \mathrm{N}$ and longitudes $58^{\circ} 15^{\prime}$ to $61^{\circ} 13^{\prime} \mathrm{E}$. The average altitude of the basin is $1846 \mathrm{~m}$ above the sea level, and the eastern part is geographically low, while the western part is high. The KRB has a cold and semi-arid climate with low annual rainfall and high evapotranspiration due to the topographic conditions (Afshar et al., 2017). The mean annual precipitation for this basin is about $340 \mathrm{~mm}$, and the highest rainfall occurs between January and May according to the recorded climate data (Afshar et al., 2017). The mean annual minimum and maximum temperatures during 1992-2005 were $7.1{ }^{\circ} \mathrm{C}$ and $20.6{ }^{\circ} \mathrm{C}$, respectively (Afshar et al., 2017). Torogh and Kardeh dams lie in the south and north of Mashhad, respectively, as the most populated cities in this area, providing water for agricultural and drinking sectors (Fig. 1). The topography of KRB, and the location of gauging and meteorological stations are depicted in Fig. 1.

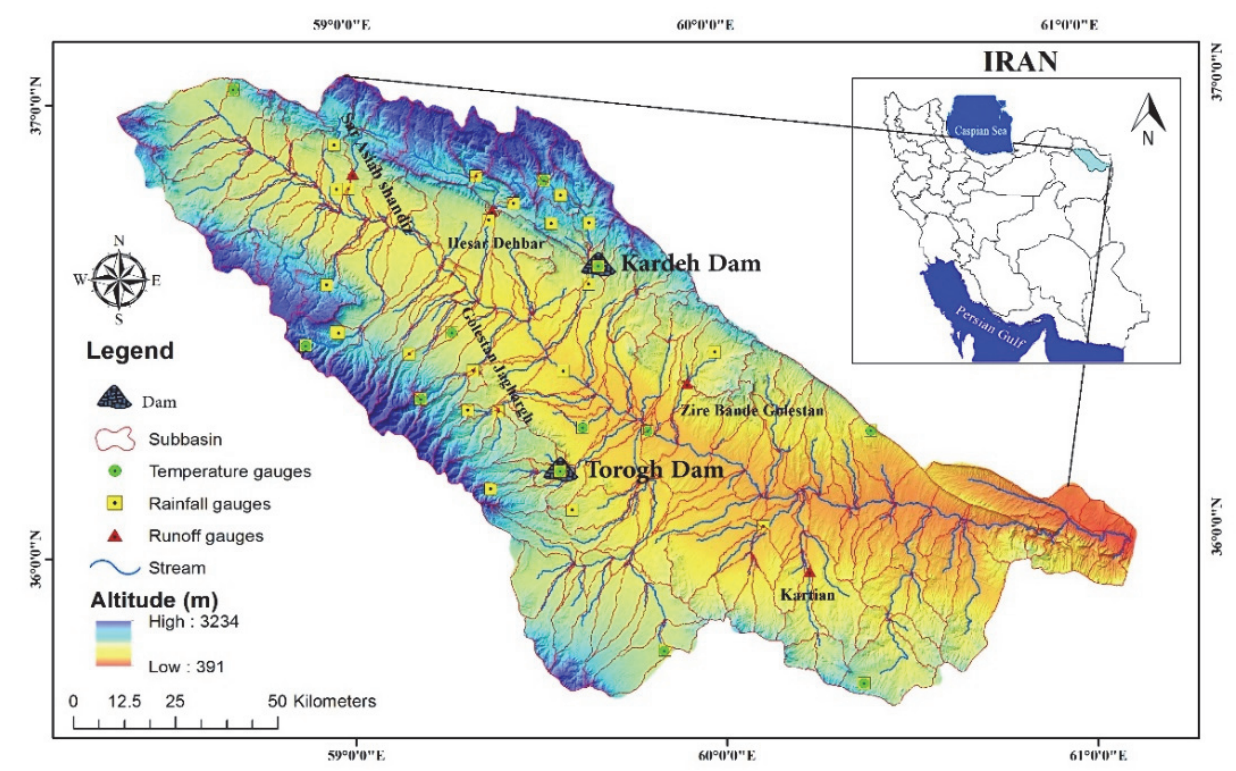

Fig. 1. DEM (digital elevation model) and the location of gauging and meteorological stations in KRB. 


\subsection{SWAT model, required data, and model set up}

SWAT, as a continuous-term, semi-distributed, process-based model, is developed to assess alternative management strategies for short- and long-term decisions in large river basins (Arnold et al., 2012) by policymakers. SWAT model has been widely applied at regional (Rahimpour et al., 2020; Hassanzadeh et al., 2019; Samuels et al., 2018; Huang et al., 2017; Rodrigues et al., 2014), national (Liu et al., 2017; Zhu et al., 2015; Faramarzi et al., 2009) and continental scales (Giles et al., 2019; Faramarzi et al., 2013). The basin of this model is classified into multiple sub-basins, and then the soil and topographical features are classified into hydrological response units (HRUs) according to the combination of land uses (Afshar et al., 2018; Cuceloglu et al., 2017; Arnold et al., 2012).

The digital elevation model (DEM) for this research is extracted from topographic maps of the National Geographic Center (NGC) of Iran. The land-use map is obtained from the Indian Remote Sensing (IRS-1C) satellite images of 2002 with a spatial resolution of 23.6 meters. According to the satellite images of KRB and IRS-1C, KRB was classified into seven land-use and land-cover classes (Fig. 2a). Pasture $(50.91 \%)$, generic agricultural $(28.56 \%)$, and winter wheat $(15.55 \%)$ lands form the majority portion of KRB and play fundamental role in the residents' economy. The studied watershed also consists of forest-evergreen (3.03\%), urban $(1.42 \%)$, range-brush, and water $(0.5 \%)$ areas. The soil map was constructed by the Range and Watershed Department (RWD) and Agriculture Jehad Organization (AJO) of Khorasan Razavi Province (KRP), which is prepared using Landsat TM satellite with a resolution of 30 meters and classified into 19 soil types (Fig. 2b). Soil data, including rock fragment, silty sand, and clay contents, soil electrical conductivity (ECe), organic carbon content, water content, bulk density, porosity, soil hydrologic groups, and saturated hydraulic conductivity (Ks) were obtained from the soil map (which was divided into nineteen classes).
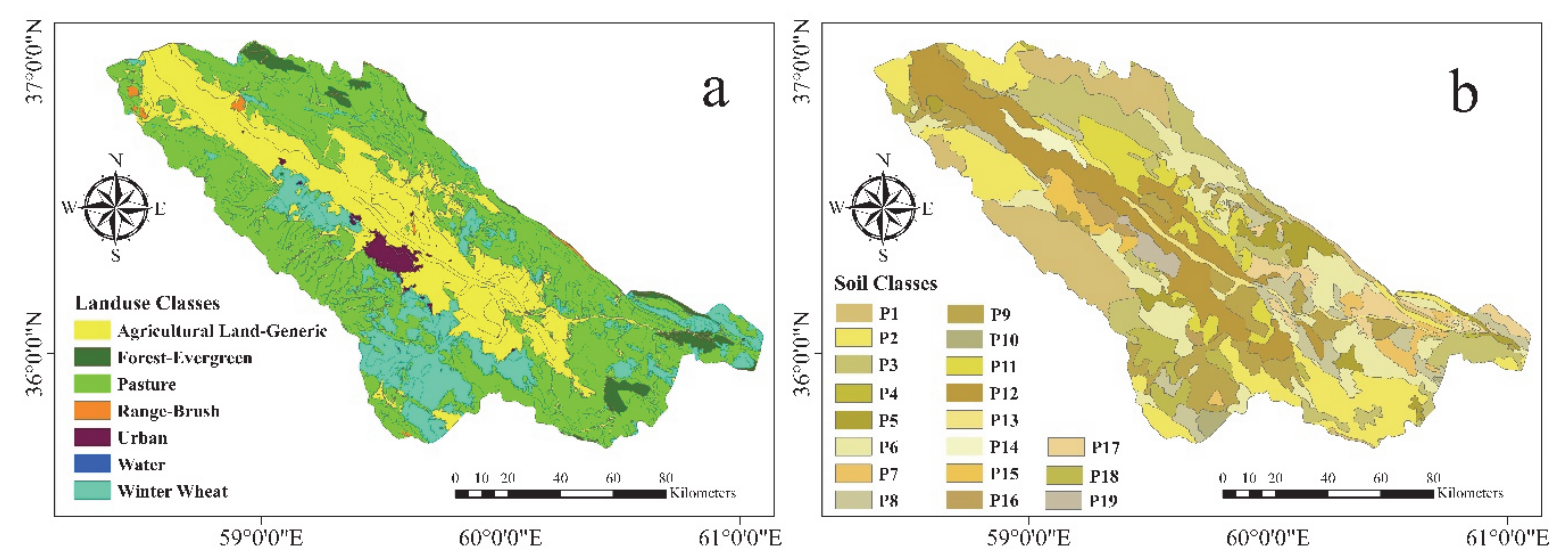

Fig. 2. Input maps to SWAT model (a. land-use and b. soil map) in KRB. 
The Iran Meteorological Organization (IMO) developed the climate database of precipitation and temperature stations, located within the watershed (during 1992-2013). Monthly river discharge data of 5 stations, needed for the calibration/validation process, were recieved from the Iran Water Resource Management Company (IWRCM). Although, there are more flow stations located in this area, only five stations (Table 1) were found to be suitable in this work. The five hydrometric and rain gauge stations were established by the IWRCM in 1978, and they are already under the control of IWRCM. These stations are flood alarming stations, which are recently equipped with several instruments such as limnograph, data logger, teleferic bridge and real-time data transmitters.

Table 1. Overview of hydrometric multi-site stations in KRB

\begin{tabular}{lccccc}
\hline \hline Stations & Symbol & Altitude & Latitude & Longitude & $\begin{array}{c}\text { Mean monthly } \\
\text { flow }\left(\mathbf{m}^{3} / \mathbf{s}\right)\end{array}$ \\
\hline \hline Sar Asiab Shandiz & SARASSHA & $1249 \mathrm{~m}$ & 36.40 & 59.34 & 0.51 \\
Zire Band Golestan & ZIRBAGOL & $1164 \mathrm{~m}$ & 36.32 & 59.43 & 0.71 \\
Golestan Jaghargh & GOLHAGHR & $1213 \mathrm{~m}$ & 36.31 & 59.40 & 0.19 \\
Hesar Dehbar & HESDEHB & $1249 \mathrm{~m}$ & 36.31 & 59.04 & 0.29 \\
Kartian & KARTIAN & $1232 \mathrm{~m}$ & 36.17 & 59.51 & 0.36 \\
\hline
\end{tabular}

The model setup in this study is carried out by the ArcSWAT 2012 interface, and the basin is divided into 217 sub-basins and subsequently divided into 635 hydrologic response units (HRUs) to evaluate the condition of GW and BW in small scales. Generally, these HRUs were determined in the model with threshold values of 20,20, and 10 percent for land-use, soil, and slope, respectively. We concluded that small polygons with an area of less than 25 hectares could be integrated into larger polygons in the vicinity by considering the overlapping maps, based on their scale, and defining these thresholds.

\subsection{Sensitivity, calibration, and uncertainty analysis}

Twenty parameters were considered in the sensitivity analysis to enhance the understanding of sensitive parameters' impacts on the stream flow (Table 2). Predefined or prior range of SWAT parameters were mostly adopted from literature (Zadeh et al., 2017; Nossent and Bauwens, 2012; Abbaspour et al., 2007), which may be considered as constant ranges in the majority of cases. 
Table 2. Parameters used for the sensitivity analysis

\begin{tabular}{|c|c|c|c|}
\hline Parameters & Group process & Explanations & $\begin{array}{l}\text { Prior } \\
\text { ranges }\end{array}$ \\
\hline SFTMP & \multirow{5}{*}{ Snow } & Snowfall temperature & -5 to 5 \\
\hline SMTMP & & Snow melt base temperature & -5 to 5 \\
\hline SMFMN & & Melt factor for snow on December 21 & 0 to 10 \\
\hline SMFMX & & Melt factor for snow on June 21 & 0 to 10 \\
\hline TIMP & & Snow pack temperature lag factor & 0.01 to 1 \\
\hline SOL_K & \multirow{4}{*}{ Soil water } & Saturated hydraulic conductivity & -0.8 to 0.8 \\
\hline SOL_BD & & Moist bulk density & -0.3 to 0.3 \\
\hline SOL_AWC & & Available water capacity of the soil layer & -0.3 to 0.3 \\
\hline SOL_ALB & & Moist soil albedo & -0.5 to 0.5 \\
\hline GW_DELAY & \multirow{7}{*}{ Groundwater } & Groundwater delay time & 0 to 400 \\
\hline GW_REVAP & & Groundwater "revap" coefficient & 0.02 to 0.2 \\
\hline GWQMN & & $\begin{array}{l}\text { Threshold depth of water in shallow aquifer } \\
\text { for return flow }\end{array}$ & 0 to 500 \\
\hline SHALLST & & Initial depth of water in the shallow aquifer & 0 to 1000 \\
\hline ALPHA_BF & & Base-flow alpha factor & 0 to 1 \\
\hline RCHRG_DP & & Deep aquifer percolation fraction & 0 to 1 \\
\hline REVAPMN & & $\begin{array}{l}\text { Threshold depth of water in shallow aquifer } \\
\text { for "revap" }\end{array}$ & 0 to 100 \\
\hline EPCO & \multirow{3}{*}{ Evapotranspiration } & Plant uptake compensation factor & 0.01 to 1 \\
\hline ESCO & & Soil evaporation compensation factor & 0.01 to 1 \\
\hline OV_N & & Manning's ' $n$ ' value for overland flow & 0 to 0.08 \\
\hline CH_K2 & \multirow{2}{*}{ Channel flow } & $\begin{array}{l}\text { Effective hydraulic conductivity in the main } \\
\text { channel }\end{array}$ & 0 to 150 \\
\hline CH_N2 & & Manning's " $n$ " value for the main channel & 0 to 0.3 \\
\hline РCPMМ & \multirow{3}{*}{ Precipitation } & Average or mean total monthly precipitation & -0.5 to 0.5 \\
\hline PCPSKW & & $\begin{array}{l}\text { Skew coefficient for daily precipitation in } \\
\text { month }\end{array}$ & -0.5 to 0.5 \\
\hline PCPSTD & & $\begin{array}{l}\text { Standard deviation for daily precipitation in } \\
\text { month }\end{array}$ & -0.5 to 0.5 \\
\hline SURLAG & \multirow{3}{*}{ Overland flow } & Surface runoff lag coefficient & 1 to 24 \\
\hline MSK_CO1 & & $\begin{array}{l}\text { Calibration coefficient used to control impact } \\
\text { of the storage time constant for normal flow }\end{array}$ & 0 to 10 \\
\hline MSK_CO2 & & $\begin{array}{l}\text { Calibration coefficient used to control impact } \\
\text { of the storage time constant for low flow }\end{array}$ & 0 to 10 \\
\hline $\mathrm{CN} 2$ & Runoff generation & Curve number & -0.4 to 0.4 \\
\hline SLSUBBSN & Geomorphology & Average slope length (m) & 10 to 150 \\
\hline
\end{tabular}


The aim of the research is to apply a comprehensive sensitivity analysis method based on the Latin hypercube sampling (LHS) theory and the Kolmogorov-Smirnov (K-S) test called generalized sensitivity analysis (GSA, also referred as regionalized sensitivity analysis, RSA) in sensitivity evaluation of SWAT model parameters. The main objective of sensitivity analysis is to understand how different components of a model (parameters) affect the outputs of the model, and its results are very effective for model calibration and model uncertainty analysis (Sobol, 2001). Additionally, sensitivity analysis also allows ranking the most important variables influencing the simulated process. One of the most widely used types of comprehensive sensitivity analysis methods is the regional sensitivity analysis (RSA) method (Freer et al., 1996). The RSA method is sampled from the parametric space of model via the Latin hypercube (LH) random sampling method. Therefore, the set of different parameters is randomly generated and then the corresponding model outputs are evaluated after the execution of the model. The Latin hypercube method is in fact the same as the Monte Carlo (MC) sampling method with the difference of that sampling is done at equal distances from the logical range of each variable, which increases the accuracy of MC simulation (Mckay et al., 1979). MC methods are numerical for generating random variables in such a way to maintain the properties of distribution function governing them. The set of parameters produced based on the values of their corresponding objective function (a criterion of the difference between the model output and the measured values) are arranged and divided in to two categories of good (X1) and bad (X2) parameters after being sampled from the parameter space. The cumulative distribution functions (CDFs) of the model parameters are then compared with each other via the Kolmogorov-Smirnov test:

$$
\mathrm{KS}=\max (|F 1(x)-F 2(x)|),
$$

where, $F 1$ and $F 2$ are generalized distribution functions of the first and second parameter sets, respectively. Besides, the higher the KS in this test, the greater the probability of two distributions being different that indicates, that the corresponding parameter is more sensitive. The Nash-Sutcliffe (NS) criterion is also used as the objective function.

The SWAT model, based on monthly observed runoff at the mentioned stations, was calibrated and validated using the SUFI-2 algorithm. However, some vital details are provided below.

The SUFI-2 algorithm, as a one-at-a-time method for calibration and validation analysis in the SWAT-CUP program, provides a narrow range of measured data within $95 \%$ prediction uncertainty (95PPU) by recognizing those parameters contributing to the reduction of total uncertainty in the output data (Van Griensven et al., 2006). Four indices, applied for quantifying the reliability of calibration and validation performance, are the Nash and Sutcliffe (NS) efficiency, coefficient of determination $\left(\mathrm{R}^{2}\right), \mathrm{P}$, and $\mathrm{R}$-factor (Abbaspour et al., 2007): 
- The NS efficiency criterion, as a performance metric, demonstrates the goodness-of-fit between the simulated and observed data (Nash and Sutcliffe, 1970). The formula is given as follows:

$$
N S=1-\frac{\sum_{i=1}^{N}\left(O_{i}-S_{i}\right)^{2}}{\sum_{i=1}^{N}\left(O_{i}-\bar{O}\right)^{2}},
$$

where $N$ is the number of observed data, $O_{i}$ and $S_{i}$ are the observed and simulated sunoff data in step $i$.

- The P-factor, indicating the observed data proportion identified by the prediction uncertainty of $95 \%$, is frequently stated as 95PPU (Abbaspour, 2007). The R-factor correspounds to the average thickness of the 95PPU band (within the upper and lower boundaries) divided by the standard deviation of the associated measured variable (Abbaspour, 2007):

$$
R-\text { factor }=\frac{\sum_{i=1}^{N}\left(Y_{U p p e r}-Y_{\text {Lower }}\right)_{i}}{N \sigma_{x}}
$$

where $Y_{\text {Upper }}$ and $Y_{\text {Lower }}$ are the upper and lower limits of the 95PPU, $\sigma_{x}$ is the standard deviation of the observed data, and $N$ is the number of the observed data.

- The coefficient of determination $(R 2)$ represents the proportion of total variance in the observed data that can be explained by the model:

$$
R^{2}=\left\{\frac{\sum_{i=1}^{N}\left(O_{i}-\bar{O}\right) *\left(S_{i}-\bar{S}\right)}{\left[\sum_{i=1}^{N}\left(O_{i}-\bar{O}\right)^{2}\right]^{0.5} *\left[\sum_{i=1}^{N}\left(S_{i}-\bar{S}\right)^{2}\right]^{0.5}}\right\}^{2}
$$

where $N, Y_{\text {Lower }}, Y_{\text {Upper, }}$, and $\sigma_{x}$ are the total number of observed data, the lower and upper limits of the 95PPU, and the standard deviation of observed data, respectively. $O_{i}$ and $S_{i}$ are the observed and simulated runoff data in step $i$, and $\bar{O}$ and $\bar{S}$ are the mean observed and simulated runoff data. P-factor and $R^{2}$ range from 0 to 100 , and $R$-factor and $N S$ coefficient range from 0 to $\infty$ and $-\infty$ to 1 , respectively. When the $P$-factor and $R^{2}$ are close to 100 percent, $R$-factor is close to 0 , and the NS coefficient is between 0.75 to 1 . The best fit among simulated and observed data is obtained during calibration and uncertainty analysis.

The goodness-of-fit is calculated between the measured and simulated runoff with $N S, R^{2}, P$, and $R$ criteria in the calibration process, after each iteration (500 runs) with twenty parameters and NS as a likelihood function for each of the 5 runoff stations, to conduct calibration until the performance criteria were 
satisfied. If these criteria are satisfied in all stations, the calibration process would be finished and parameter ranges would be applied to investigation in the validation process and to extract BW, GWF, and GWS components. Otherwise, new parameter ranges are proposed for the next iteration. The final upper and lower bounds of the parameters as well as the fitted values of parameters were obtained after one or more iterations. Time periods from 1992 to 2011 were used for calibration (2001-2011) and validation (1995-2000) processes. Also, the first three years (1992-1995) were applied to warm-up the model. The calibrated parameter ranges were used without any change with the same number of simulations as utilized for calibration in the validation process. The efficiency measures were computed during the calibration process, as well. Details of the procedures for validation, calibration, sensitivity and uncertainty analysis can be found in the study conducted by Afshar et al. (2018).

\subsection{Climate change models and scenarios}

Fourteen climate change models, among the sixty one models of CMIP5, are used frequently to simulate future climate conditions in Asia (Afshar et al., 2017; Woldemeskel et al., 2016; Salzmann et al., 2014; Jiang and Tian, 2013; Chaturvedi et al., 2012). Their outputs of GCMs are appropriate for simulation of climatic data at a meteorological station in a regional location using highresolution GCMs due to the downscaling process (Duan and Mei, 2014). In this research, the monthly climate data (precipitation and temperature) of CMIP5 models for different time periods were extracted from the CMIP3 and CMIP5 Climate and Hydrology Projections website (https://gdo-dcp.ucllnl.org/). These data are downscaled using the bias-correction spatial disaggregation (BCSD) method (for more details, refer to Afshar et al. (2017)).

The earth system models (ESMs) are frequently applied as coupled climate models to simulate biogeochemical components. The leading institutions in the climate field also establish them. The MIROC-ESM was developed by the Japan Agency for Marine-Earth Science and Technology (JAMSTEC) in cooperation with the University of Tokyo and the National Institute for Environmental Studies (NIES) (Nozawa et al., 2007). The latest version of the mentioned model has some limited functions due to the uncertainty in coupling processes, and only includes the impact of vegetation changes on dust emission and impact of deposition of dust and black carbon on snow albedo (Watanabe et al., 2011). On the other hand, the Geophysical Fluid Dynamics Laboratory (GFDL) of the National Oceanic and Atmospheric Administration (NOAA) released their new ocean climate model in 2012, which is based on density layers to understand the impact of the earth's biogeochemical cycles including human activities in collaborating with the climate system (Dunne et al., 2013, 2012). The GFDL also developed the Geophysical Fluid Dynamics Laboratory Earth System Model with the Generalized Ocean Layer Dynamics component (GFDL-ESM2G) model (Dunne et al., 2013, 2012). The 
GFDL-ESM2G model is a fully-coupled Atmosphere-Ocean General Circulation Model (AOGCM) with an interactive closed carbon cycle and does not exhibit a clear La Niña-like response. Recently, both models have been applied at different scales and locations (Samuels et al., 2018; Sylla et al., 2015). The longitude (and latitude) resolution of MIROC-ESM is about $2.8125^{\circ}$ (and $2.796^{\circ}$ ) and in the GFDL-ESM2G model this resolution is about $2.5000^{\circ}$ (and $2.0225^{\circ}$ ).

According to Afshar et al. (2017), MIROC-ESM and GFDL-ESM2G models were selected in this study among 14 climate models based on the evaluation criteria, i.e., the Nash-Sutcliffe (NS) efficiency coefficient, the percent of bias (PBIAS), the coefficient of determination $\left(\mathrm{R}^{2}\right)$, the ratio of the root mean square error to the standard deviation (RSR) (Table 3), and the performance rating of simulation model (Moriasi et al., 2007). Both models showed the highest agreement with observational data in KRB based on the evaluation criteria. (For more explanation about the methodology of selecting these two CMIP5 models refer to Afshar et al., 2017).

Table 3. Reported performance rating of evaluation criteria for the outputs of 14 CMIP5 models (Afshar et al., 2017)

\begin{tabular}{|c|c|c|c|c|}
\hline \multirow{2}{*}{$\begin{array}{c}\text { Rating based on } \\
\text { (Moriasi et al,. } \\
\text { 2007) } \\
\end{array}$} & \multicolumn{4}{|c|}{ Criteria Evaluation } \\
\hline & NS & PBIAS (\%) & $\mathbf{R}^{2}$ & RSR \\
\hline Very good (VG) & $0.75<\mathrm{NS} \leq 1.00$ & PBIAS $\leq \pm 10.00$ & $0.866 \leq \mathrm{R}^{2}<1.00$ & $0 \leq \mathrm{RSR} \leq 0.5$ \\
\hline Good (G) & $0.65<\mathrm{NS} \leq 0.75$ & $\pm 10 \leq$ PBIAS $< \pm 15$ & $0.733 \leq \mathrm{R}^{2}<0.866$ & $0.5<\mathrm{RSR} \leq 0.6$ \\
\hline Satisfactory (S) & $0.50<\mathrm{NS} \leq 0.65$ & $\pm 15 \leq$ PBIAS $< \pm 25$ & $0.60 \leq \mathrm{R}^{2}<0.733$ & $0.6<\mathrm{RSR} \leq 0.7$ \\
\hline Unsatisfactory (US) & $\mathrm{NS}<0.50$ & PBIAS $\geq \pm 25$ & $\mathrm{R}^{2}<0.6$ & $\mathrm{RSR}>0.7$ \\
\hline Models & \multicolumn{4}{|c|}{ Criteria values } \\
\hline HadGEM2-ES & $0.57(\mathrm{~S})$ & $-17.15(\mathrm{~S})$ & $0.69(\mathrm{~S})$ & 0.73 (US) \\
\hline IPSL-CM5A-LR & $0.71(\mathrm{G})$ & $-15.65(\mathrm{~S})$ & $0.81(\mathrm{G})$ & $0.61(\mathrm{~S})$ \\
\hline NorESM1-M & $0.88(\mathrm{VG})$ & $-4.74(\mathrm{VG})$ & $0.92(\mathrm{VG})$ & $0.51(\mathrm{G})$ \\
\hline BCC-CSM1.1 & $0.62(\mathrm{~S})$ & $-11.01(\mathrm{G})$ & $0.74(\mathrm{G})$ & $0.67(\mathrm{~S})$ \\
\hline CCSM4 & 0.43 (US) & -28.15 (US) & 0.52 (US) & 0.79 (US) \\
\hline MIROC-ESM & 0.95 (VG) & $-2.88(V G)$ & 0.97 (VG) & 0.33 (VG) \\
\hline CSIRO-MK3.6.0 & $0.51(\mathrm{~S})$ & -27.44 (US) & $0.60(\mathrm{~S})$ & $0.71(\mathrm{US})$ \\
\hline GFDL-ESM2M & $0.66(\mathrm{G})$ & $-10.4(\mathrm{G})$ & $0.79(\mathrm{G})$ & $0.64(\mathrm{~S})$ \\
\hline GFDL-ESM2G & $0.92(\mathrm{VG})$ & $-2.93(V G)$ & 0.94 (VG) & 0.37 (VG) \\
\hline CESM1(CAM5) & $0.55(\mathrm{~S})$ & -26.36 (US) & $0.63(\mathrm{~S})$ & $0.68(\mathrm{~S})$ \\
\hline GFDL-CM3 & 0.48 (US) & -26.03 (US) & $0.54(\mathrm{US})$ & 0.74 (US) \\
\hline $\begin{array}{l}\text { MIROC-ESM- } \\
\text { CHEM }\end{array}$ & $0.78(\mathrm{VG})$ & $-5.25(\mathrm{VG})$ & $0.71(\mathrm{~S})$ & $0.66(\mathrm{~S})$ \\
\hline IPSL-CM5A-MR & $0.85(\mathrm{VG})$ & $-4.96(\mathrm{VG})$ & $0.85(\mathrm{G})$ & $0.46(\mathrm{VG})$ \\
\hline MIROC5 & $0.60(\mathrm{~S})$ & -25.75 (US) & $0.71(\mathrm{~S})$ & $0.68(\mathrm{~S})$ \\
\hline
\end{tabular}


The CMIP5 model outputs include four representative concentration pathways (RCPs) of new emission scenarios (such as RCP2.6, 4.5, 6.0, and 8.5). RCPs are based on the emission forcing level until 2100 (see Chapter 11, Sections 11.2 and 11.3, IPCC, 2013). The radiative forcing is the extra heat in the lower atmosphere that will be preserved by means of additional greenhouse gases.

In this study, RCP8.5 is applied as a high baseline emission scenario and the highest amount of greenhouse gas concentration by the end of the 21 st century (Van Vuuren et al., 2011a). The RCP8.5 radiative forcing pathway consistently rises (at a target of $8.5 \mathrm{~W} / \mathrm{m}^{2}$ in 2100), while enhancing the residual circulation furthermore and increases the level of greenhouse gases significantly (Riahi et al., 2011). Consumption of oil and coal, increasing the agricultural lands, and decreasing the forest area with current trends play an essential role in providing energy, and the population of earth will reach to 12 billion until the 22 century (Van Vuuren et al., 2011a). Therefore, the highest possible changes in climate will happen in this scenario.

Besides, we applied RCP4.5 as an intermediate pathway with no exceedance from the projected level of long-term radiative forcing. The emission will reach to the highest level in this scenario in the middle of the century, then decline in 30 years, then it stabilizes (Smith and Wigley, 2006). Renewable and nuclear powers play a greater role in this scenario, in comparison with RCP8.5 (Van Vuuren et al., 2011a). The RCP6.0 is similar to RCP4.5, but is not applied in this study due to a variety of technologies and strategies employed in the greenhouse gas emissions reduction (Hijioka et al., 2008).

Considering the urge for developing realistic climate change scenarios to make the planning of adaptation measures easier, we do not contribute RCP2.6 in the climate model group because it contains negative emissions of energy use in the second half of the 21 st century, and one of its key assumptions is the full involvement of all countries worldwide in the short term (Van Vuuren et al., 2011b). Therefore, the best selections in this research are RCP4.5 (the medium stabilization scenario) and RCP8.5 (the high emission scenario) that encompass the whole spectrum of radiative forcing arising from RCP4.5, RCP6.0, and RCP8.5.

\section{Results and discussion}

\subsection{Sensitivity, calibration, and validation}

The most sensitive parameters with their assigned rank, based on the Kolmogorov-Smirnov (K-S) test values that are illustrated in Fig. 3, shows that 20 parameters affect the results of runoff simulation and play an essential role in the calibration of SWAT model. Among these parameters, ESCO, GW_REVAP, SOL_AWC, and SFTMP were the most sensitive parameters for outflow. Although the RCHRG_DP, SOL_K, and SMTMP parameters seemed to be less 
sensitive, as indicated by their K-S test (Fig. 3), these parameters have considerably contributed to increase the model calibration results for river discharges. The fitted values of parameters, as well as the final lower and upper bounds of parameters are shown after a total of 3000 runs (six iterations) in Table 4. Results of calibration and validation from $R^{2}, N S, R$, and $P$ indices are represented in Table 5. More than $60 \%$ of the values of runoff data at all the stations can be bracketed on average in calibration (validation) by 95PPU. $N S$ values were greater than $0.60(0.64)$ in the calibration (validation) period, and $R^{2}$ was greater than $0.63(0.65)$ at all the stations. Accordingly, the calibrated model can be applied with confidence to the set of optimized parameters, and the validation period demonstrated better agreement in respect of the calibration period (Table 5).

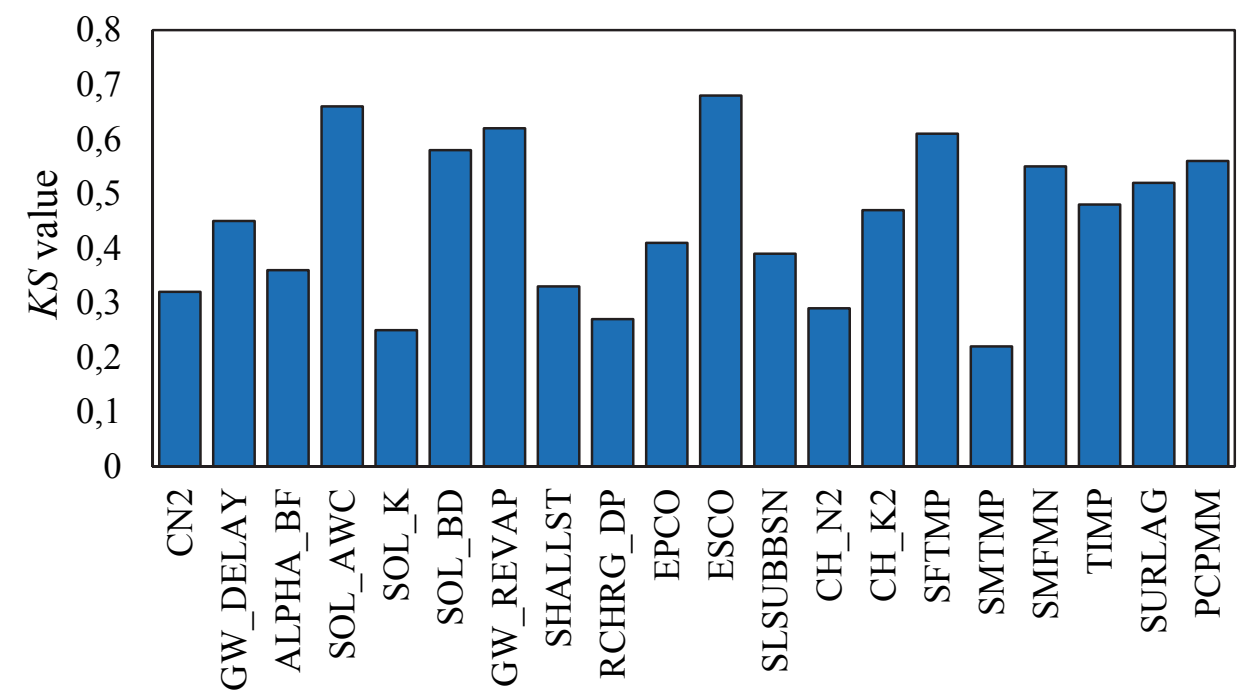

Fig. 3. Kolmogorov-Smirnov values (KS) for 20 sensitivity parameters.

Table 4. Sensitive parameters, posterior ranges, and fitted values (Afshar et al., 2018)

\begin{tabular}{lccclccc}
\hline \hline Parameters & $\begin{array}{c}\text { Range of parameter } \\
\text { Minimum }\end{array}$ & $\begin{array}{c}\text { Fitted } \\
\text { value }\end{array}$ & Parameters & $\begin{array}{c}\text { Range of parameter } \\
\text { Minimum }\end{array}$ & $\begin{array}{c}\text { Fitted } \\
\text { vaximum }\end{array}$ & value \\
\hline \hline CN2 & 0.197 & 0.281 & 0.23 & ESCO & 0.41 & 0.501 & 0.50 \\
GW_DELAY & 132.7 & 159 & 133.55 & SLSUBBSN & 96.5 & 109.5 & 99.54 \\
ALPHA_BF & 0 & 0.08 & 0.042 & CH_N2 & 0.102 & 0.13 & 0.12 \\
SOL_AWC & 0.21 & 0.28 & 0.28 & CH_K2 & 101.5 & 114 & 101.72 \\
SOL_K & 0.15 & 0.32 & -0.16 & SFTMP & -1.0 & -1.81 & -1.45 \\
SOL_BD & 0.095 & 0.167 & -0.11 & SMTMP & -0.95 & -1.92 & -1.70 \\
GW_REVAP & 0.085 & 0.115 & 0.11 & SMFMN & 7.5 & 8.95 & 8.16 \\
SHALLST & 460.8 & 510.5 & 485.30 & TIMP & 0.50 & 0.70 & 0.51 \\
RCHRG_DP & 0.229 & 0.32 & 0.24 & SURLAG & 9.60 & 12.2 & 10.22 \\
EPCO & 0.29 & 0.41 & 0.29 & PCPMM & -0.177 & -0.325 & -0.25 \\
\hline
\end{tabular}


Table 5. Monthly runoff calibration and validation results at five stations (Afshar et al., 2018)

\begin{tabular}{lcccccccc}
\hline \hline \multirow{2}{*}{ Stations } & \multicolumn{4}{c}{ Calibration period } & \multicolumn{4}{c}{ Validation period } \\
& $\boldsymbol{R}^{\mathbf{2}}$ & $\boldsymbol{N} \boldsymbol{S}$ & $\boldsymbol{R}$-factor & $\boldsymbol{P}$-factor & $\boldsymbol{R}^{\mathbf{2}}$ & $\boldsymbol{N} \boldsymbol{S}$ & $\boldsymbol{R}$-factor & $\boldsymbol{P}$-factor \\
\hline \hline SARASSHA & 0.72 & 0.71 & 1.10 & 0.57 & 0.65 & 0.64 & 0.96 & 0.56 \\
ZIRBAGOL & 0.66 & 0.65 & 1.29 & 0.58 & 0.84 & 0.83 & 0.92 & 0.65 \\
GOLJAGHR & 0.66 & 0.64 & 0.95 & 0.63 & 0.74 & 0.74 & 0.81 & 0.64 \\
HESDEHB & 0.63 & 0.60 & 0.92 & 0.74 & 0.81 & 0.81 & 0.75 & 0.78 \\
KARTIAN & 0.68 & 0.63 & 0.90 & 0.66 & 0.87 & 0.87 & 0.58 & 0.67 \\
\hline
\end{tabular}

\subsection{Spatial and temporal changes of water resources components}

We decided to divide future periods into two different sections, including nearterm perspective (2014-2042) and far-term perspective (2043-2100) with the historical period (1992-2011) in order to have a better comparison of precipitation $(\mathrm{P})$, temperature $(\mathrm{T})$, blue water $(\mathrm{BW})$, green water flow $(\mathrm{GWF})$, and green water storage (GWS) in MIROC-ESM and GFDL-ESM2G models in this work. The concentrations of $\mathrm{CO}_{2}$ for RCP4.5 and 8.5 are about 431 and $444 \mathrm{ppm}$ in the near future and are about 533 and $811 \mathrm{ppm}$ in the far future, which were used in the SWAT model.

The spatial distribution of the average values of $\mathrm{P}, \mathrm{T}, \mathrm{BW}, \mathrm{GWF}$, and GWS for the historical period is shown in Fig. 4 and the results show that the amounts of GWF (Fig. 4d) and BW (Fig. 4c) were higher in the upstream than those in the downstream for this time period due to the differences in precipitation patterns (Pandey et al., 2019; Fazeli Farsani et al., 2019; Zuo et al., 2015).

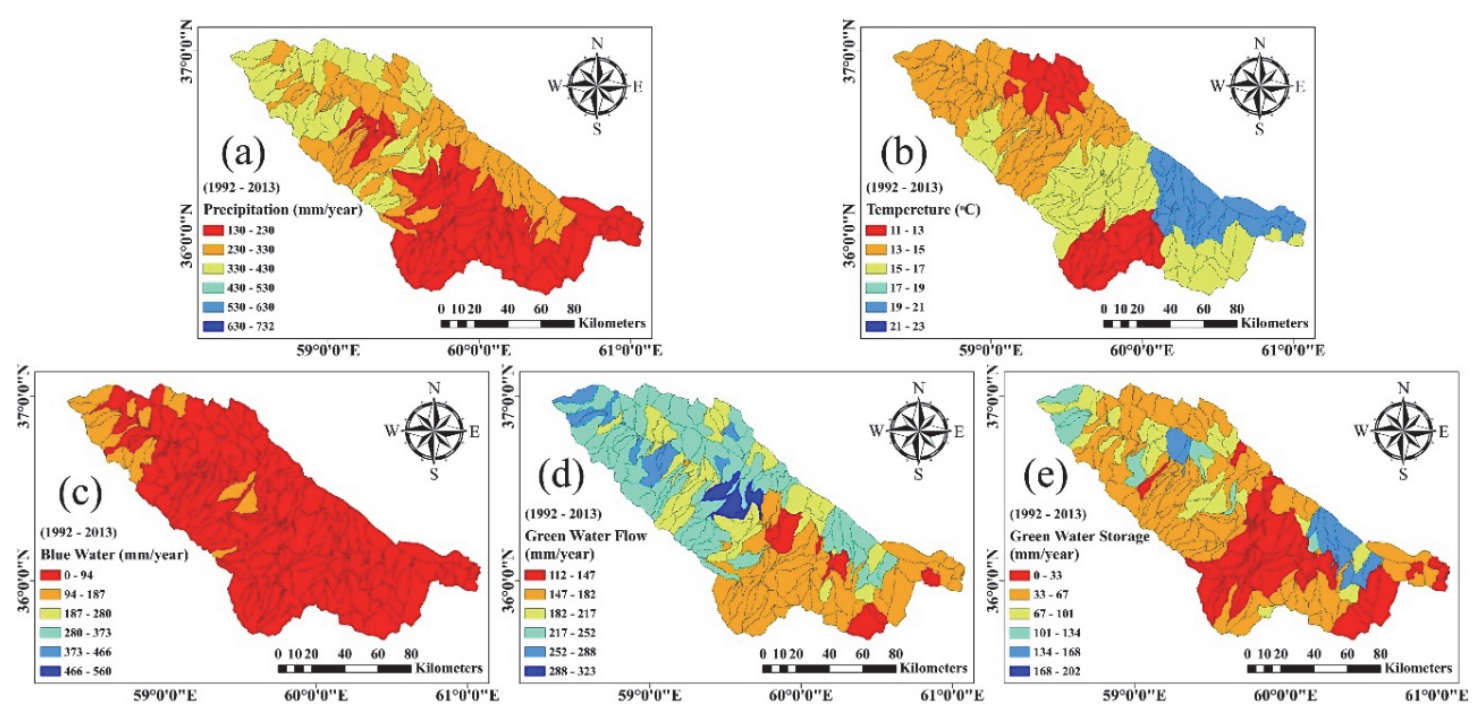

Fig. 4. Spatial pattern of mean annual water components over the KRB during the historical period. 
Fig. 5 shows the simulation results of precipitation $(\mathrm{P})$ in both models and scenarios. According to Fig. 5, the spatial variations of $\mathrm{P}$ in KRB for both RCP scenarios and periods, under the two models, show the same pattern. The highest and lowest values of this component occured in the northern and southeastern parts of the basin, respectively. The GFDL-ESM2G model provided higher rate of $\mathrm{P}$ than MIROC-ESM by comparing the results of both models in the future periods. The highest value of the mentioned component was observed in the GFDL-ESM2G model in the near future period under RCP 4.5 (Fig. 5a), while the MIROC-ESM model resulted in the lowest value of mean annual $\mathrm{P}$ in this area in the far future period (Fig. 5f) under the same RCP.

GFDL-ESM2G
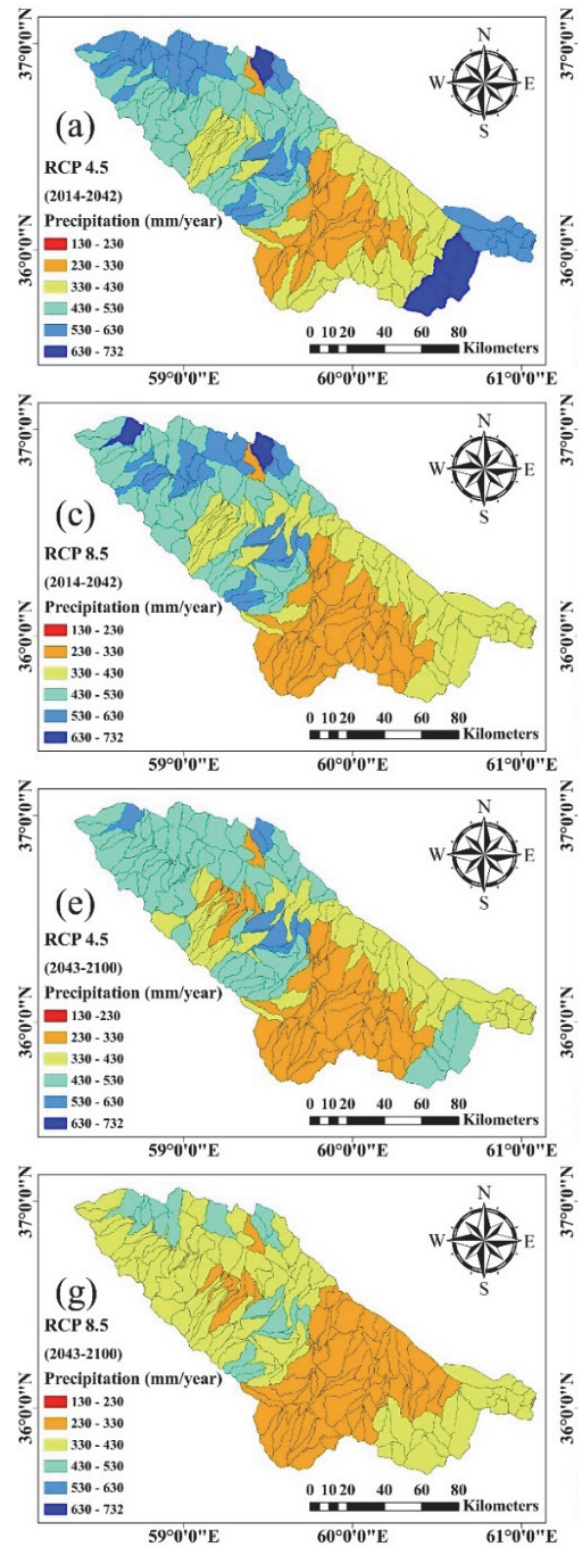

MIROC-ESM
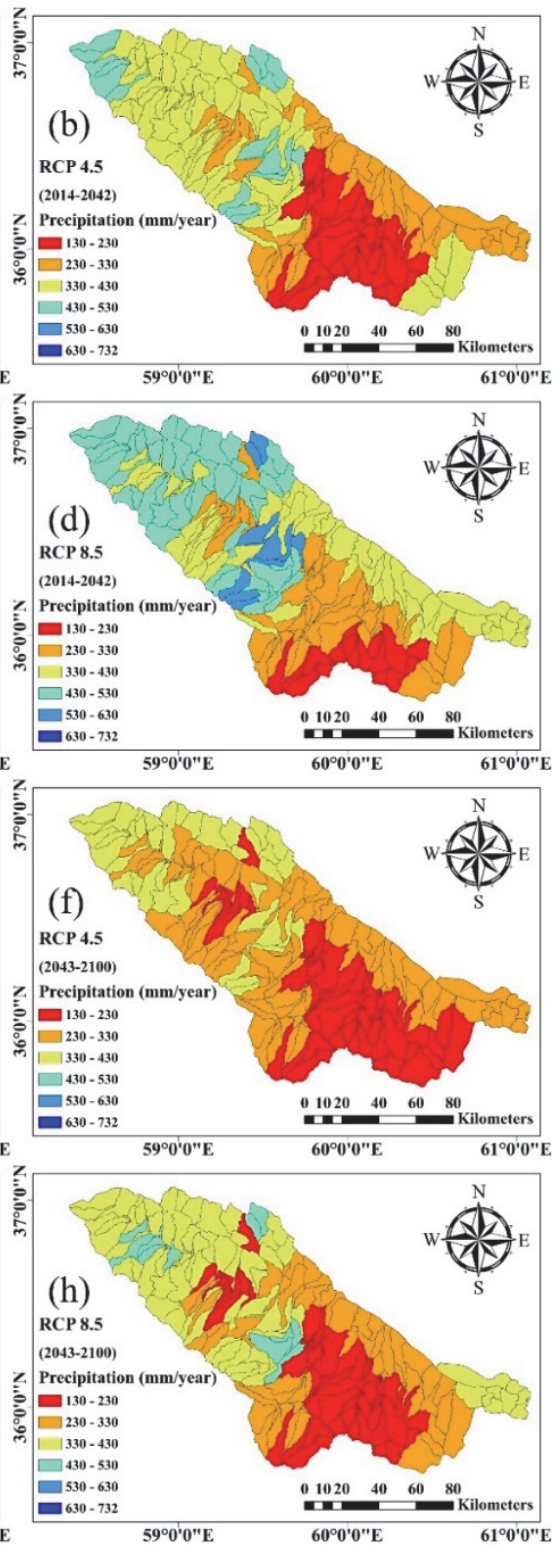

Fig. 5. Variability of precipitation, simulated under different scenarios and models for near and far future in KRB. 
Fig. 6 shows the simulation results of temperature $(\mathrm{T})$ in both scenarios and models. It is obvious that $\mathrm{T}$ will be increased by transition from near-term to farterm projection, and the spatial pattern shows that northern and high-altitude areas in the northeast and southwest would have the lowest mean annual temperature. $\mathrm{T}$ in RCP8.5 (Figs. 6c, $d$, g, and $h$ ) is higher than in RCP4.5 (Figs. $6 a, b, d$, and $f$ ), due to the high emission of greenhouse gases and the increase in $\mathrm{CO}_{2}$ concentration. The MIROC-ESM model simulated higher $\mathrm{T}$ than the other model, and the mean annual $\mathrm{T}$ is estimated to increase about $3{ }^{\circ} \mathrm{C}$ in the far future period in MIROC-ESM under RCP8.5 (Fig. 6h).

GFDL-ESM2G
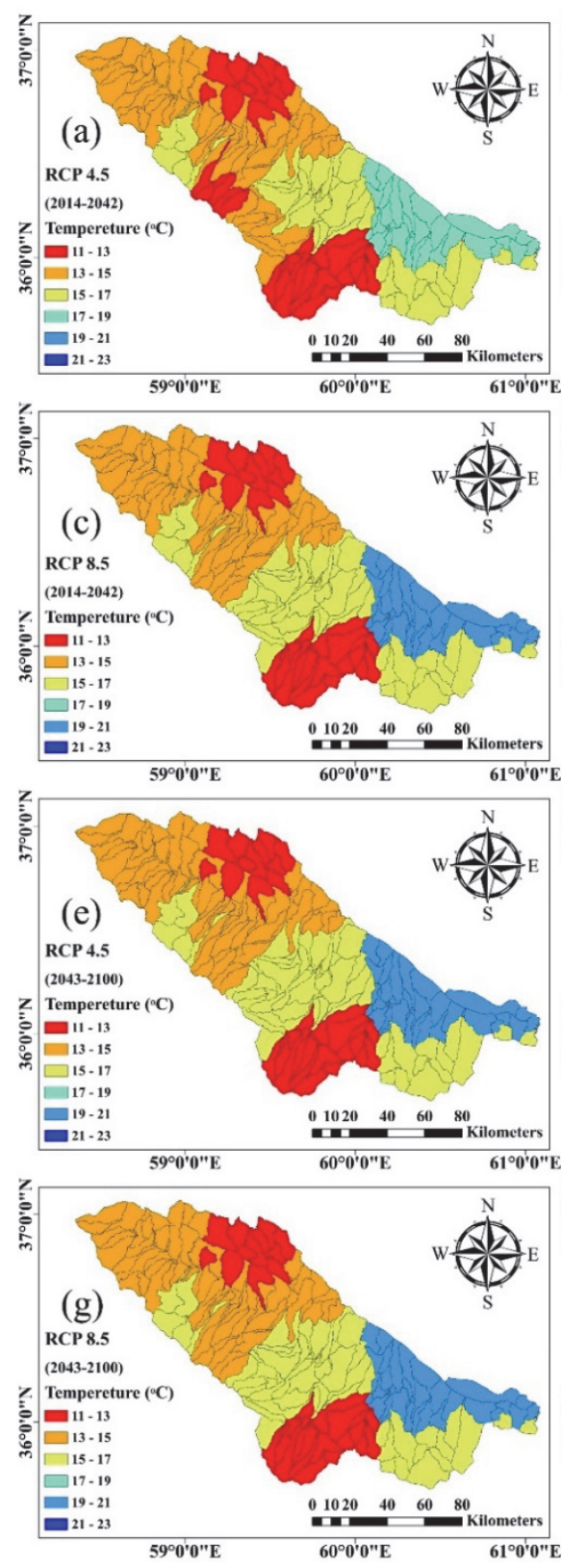

MIROC-ESM
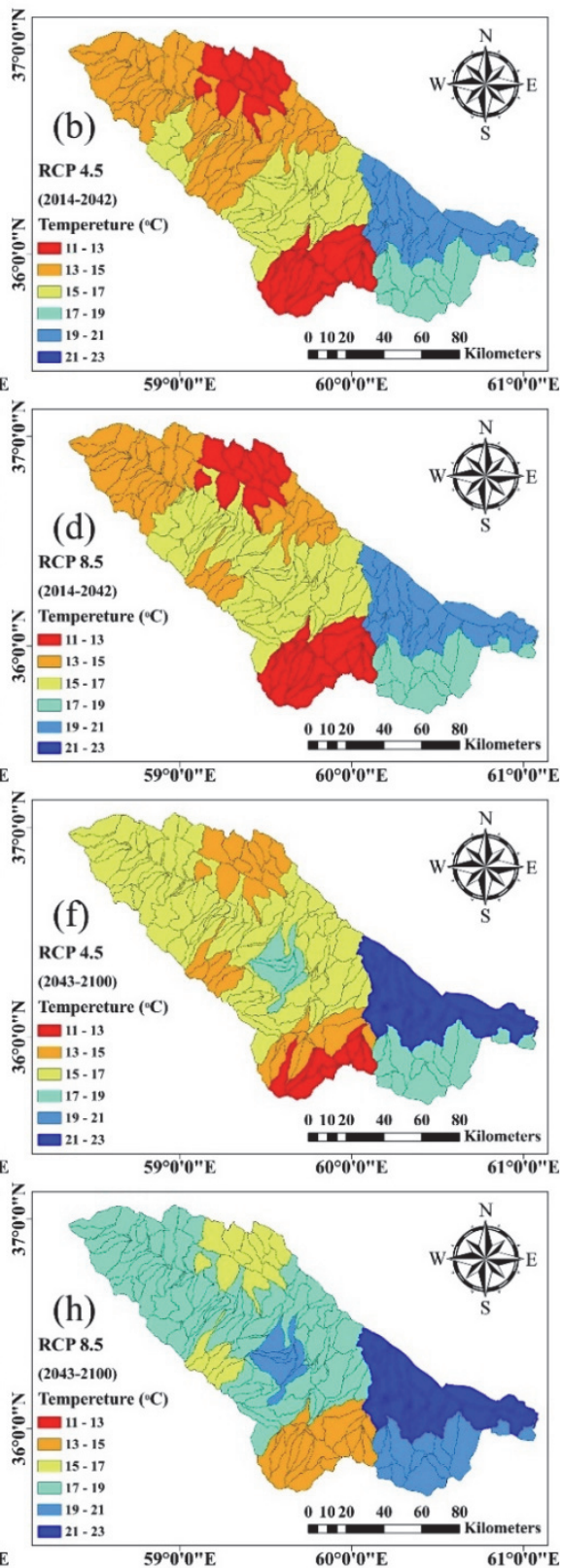

Fig. 6. Variability of temperature, simulated under different scenarios and models during the near and far future intervals in KRB. 
The results of BW simulation are shown in Fig. 7 for KRB under different scenarios and models. Generally, BW decreases from northwest to southeast in the watershed. The simulations for both models and scenarios show a decreasing trend by passing from the near-term to far-term periods. The decrease of BW in the MIROC-ESM is higher than in the other model. There is no significant variation in the spatial distribution of $\mathrm{P}$ and $\mathrm{BW}$ according to the results of $\mathrm{P}$ (Figs. 5a-h) and the direct relationship between these two components. Furthermore, the MIROCESM model estimated both components higher than the GFDL-ESM2G in the future periods. The highest (lowest) mean annual BW will occur under RCP4.5 in GFDL-ESM2G in the near future (in MIROC-ESM in the far future) period (Figs. 7a, f). It should be noted that the surface runoff is a major part of BW (Pandey et al., 2019; Fazeli Farsani et al., 2019). BW is a renewable resource and potentially necessary for the agriculture sector in this area. Therefore, the climate change will have a significant impact on agricultural activities in the study area.

\section{GFDL-ESM2G MIROC-ESM}

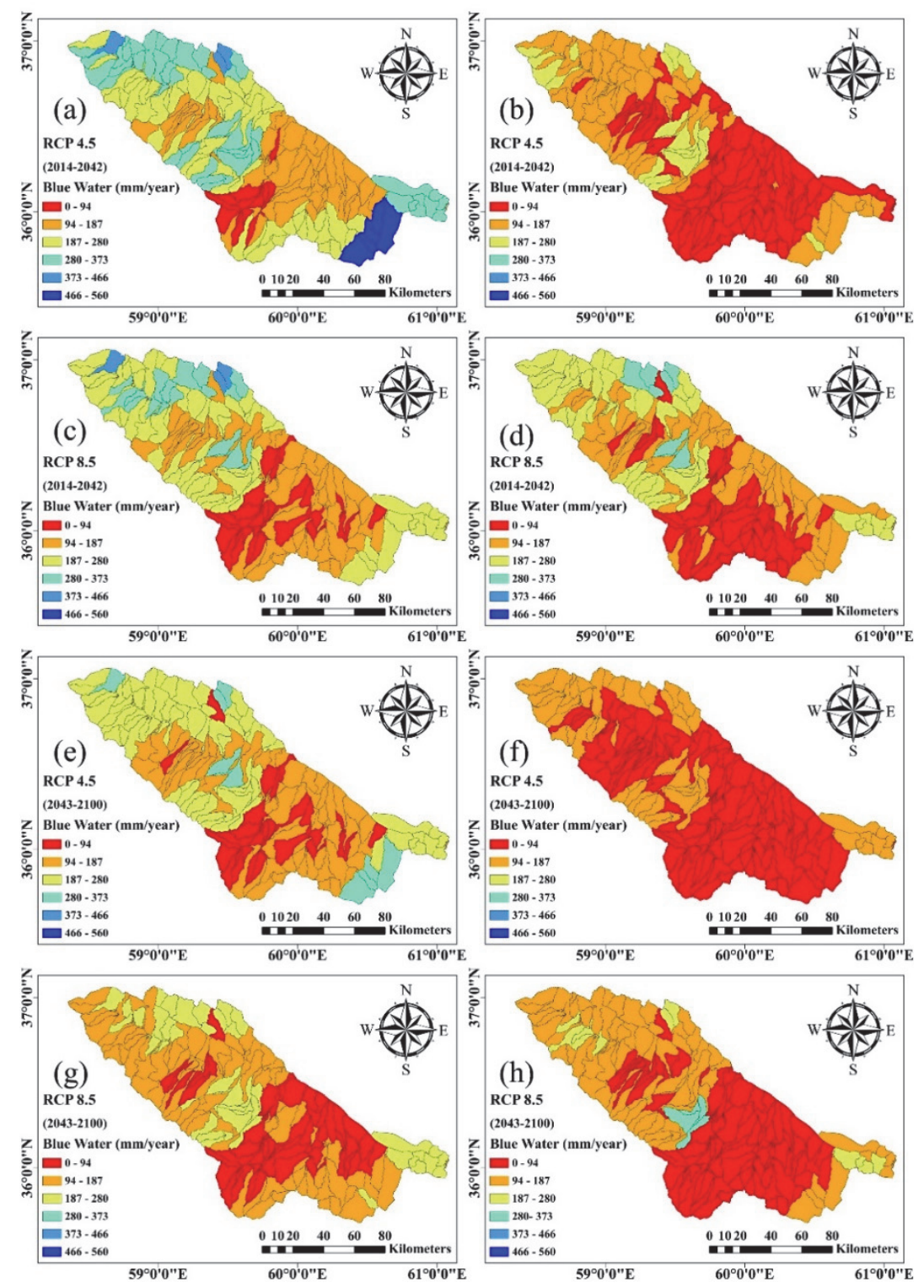

Fig. 7. Variability of BW, simulated under different scenarios and models during the near and far future intervals in KRB. 
Fig. 8 shows the average values of GWF during the near and far future periods under two scenarios and models. As temperature increases in all of our calculations (Figs. 6a-h), the actual evapotranspiration expected to be increased if there is enough water. The value of GWF in the north and northwest (upstream) parts of the KRB is greater than that in the south and southeast parts of the study area. The lack of sufficient water resources in south and southeastern parts of the basin, the vegetation, and land use are the reasons of spatial distribution. The simulations show that the mean annual GWF slightly decreases under both scenarios and models by passing from the near to far period, due to the reduction of $\mathrm{P}$. According to calculation results, GFDL-ESM2G simulates GWF slightly less than the other model throughout the near future. However, this parameter has been simulated higher than that by the MIROC-ESM during the far future by the mentioned model.

GFDL-ESM2G
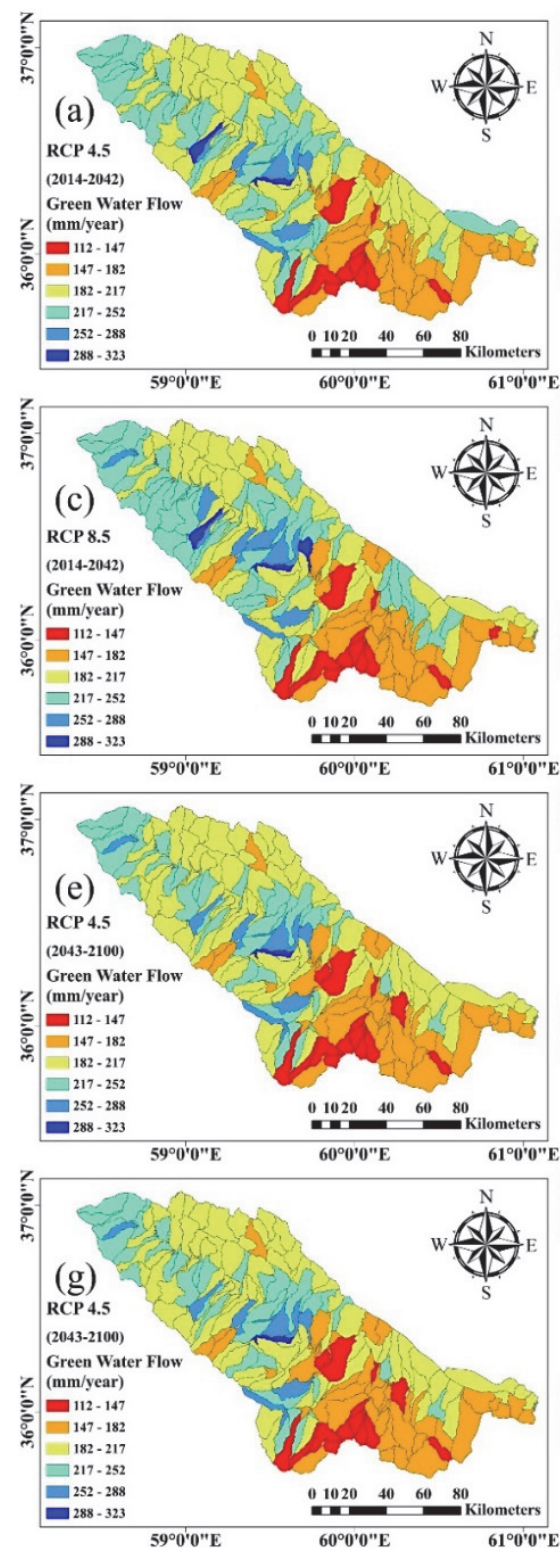

MIROC-ESM
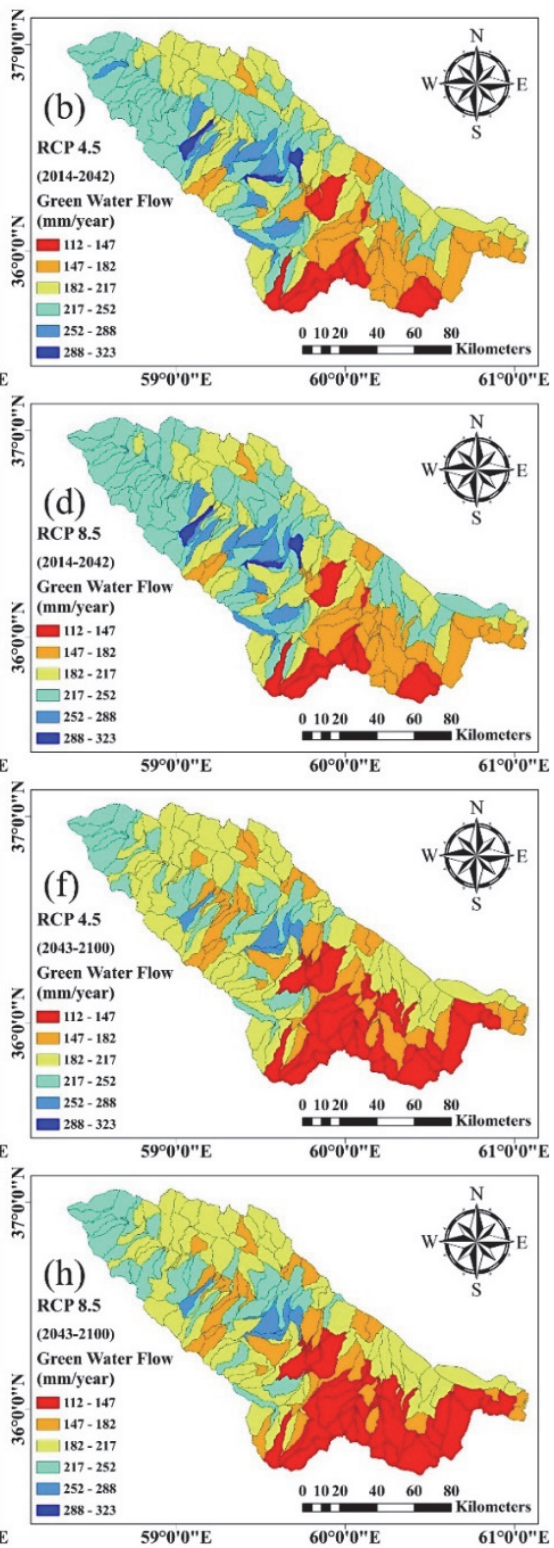

Fig. 8. Variability of GWF, simulated under different scenarios and models during the near and far future intervals in KRB. 
GWS is an important water source that sustains the earth's ecosystems, especially crops, which is a vital part of human food (Schyns et al., 2015). Fig. 9 shows the results of simulations for the average annual GWS in KRB by different models and under different scenarios. The highest and lowest mean annuals of this component are projected in MIROC-ESM in the near and far future periods under RCP4.5 (Figs. $9 b$ and $f$ ). In addition, GWS by the MIROC-ESM under RCP4.5 severely reduced by transition from the near to far period (Figs. $9 b$ and f), while it will slightly increase under RCP8.5 (Figs. 9d and $h$ ). However, GFDLESM2G shows a completely different trend. For instance, the value of GWS will decrease and increase by passing from the near to far future under RCP4.5 and RCP8.5, respectively. These findings are in a noble agreement with Pandey et al. (2019), and with Fazeli Farsani et al. (2019), Faramarzi et al. (2009), Abbaspour et al. (2009), that simulated P, BW, and GW values at the watershed scale.

GFDL-ESM2G
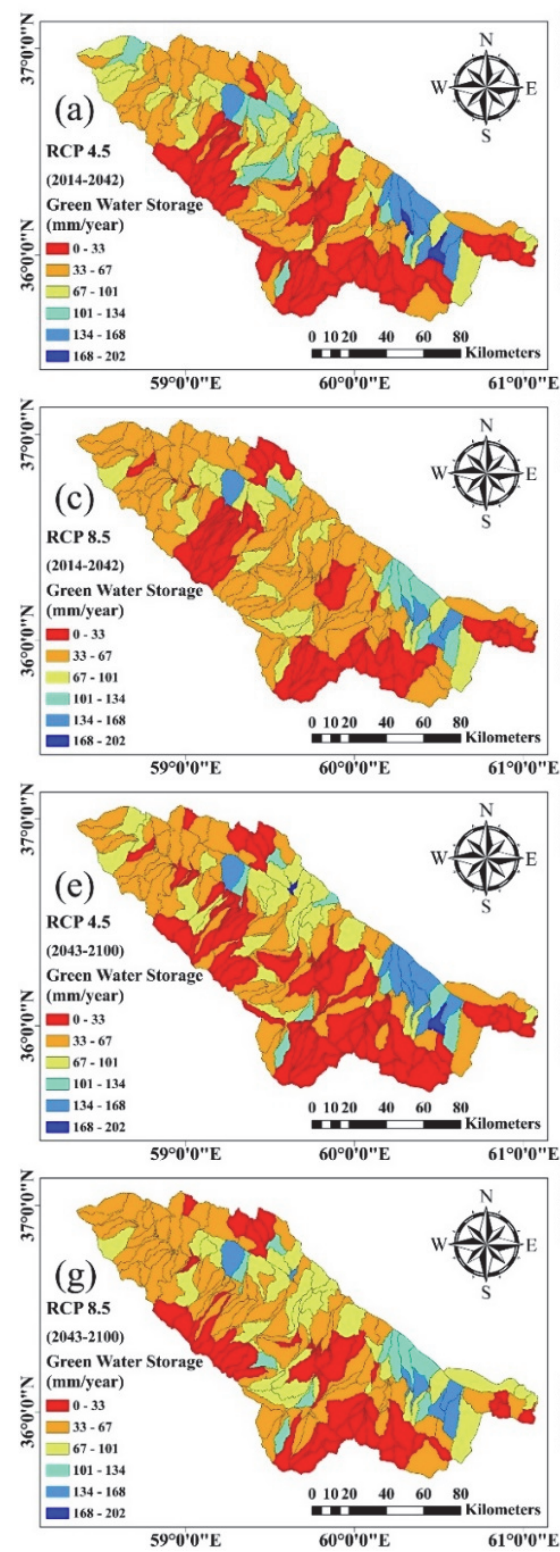

MIROC-ESM
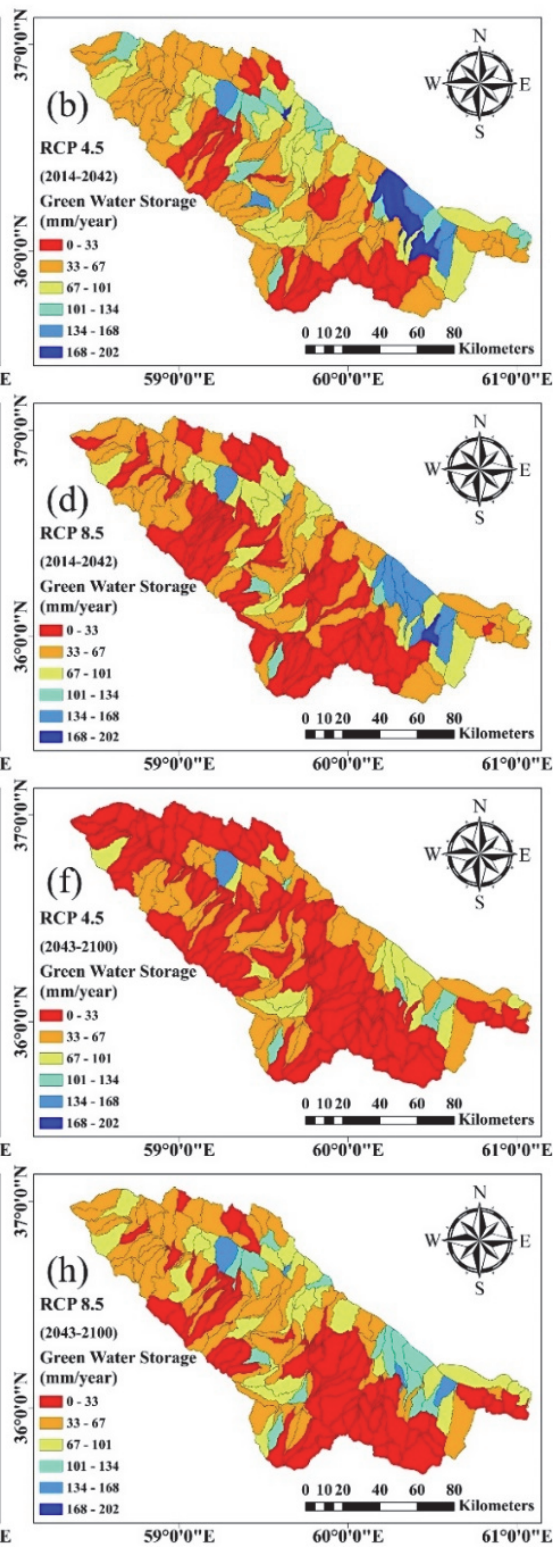

Fig. 9. Variability of GWS, simulated under different scenarios and models during the near and far future intervals in KRB. 
The main reason for abrupt variations in the components of water resources (such as GWS and GWF) among the sub-basins is due to changes in the texture and soil characteristics and water holding capacity in the sub-basins (19 profiles defined in the present research) as well as to their effect on the evapotranspiration parameters in the hydrologic model (SWAT).

The mean annual water components are shown in Table 6 in both models and RCPs and for two future periods regarding the historical period. At the same time, all the following results are compared with the historical time period. The obtained results show that BW and P increase under both scenarios, models, and future intervals compared with the historical period, and the values of $\mathrm{BW}$ and $\mathrm{P}$, simulated by the GFDL-ESM2G model in KRB, are higher than those simulated by the other model. P and T will rise during the future intervals in both models in comparison with the historical period.

Table 6. Mean annual values of water components during historical and future intervals $(\mathrm{mm} / \mathrm{yr})$

\begin{tabular}{|c|c|c|c|c|c|c|c|c|c|}
\hline \multirow{3}{*}{$\begin{array}{c}\text { Hydro- } \\
\text { climatic } \\
\text { component }\end{array}$} & \multirow{3}{*}{$\begin{array}{l}\text { Historica } \\
\text { I period }\end{array}$} & \multicolumn{4}{|c|}{ MIROC-ESM } & \multicolumn{4}{|c|}{ GFDL-ESM2G } \\
\hline & & \multicolumn{2}{|c|}{ Near } & \multicolumn{2}{|c|}{ Far } & \multicolumn{2}{|c|}{ Near } & \multicolumn{2}{|c|}{ Far } \\
\hline & & 4.5 & 8.5 & 4.5 & 8.5 & 4.5 & 8.5 & 4.5 & 8.5 \\
\hline $\mathrm{P}$ & 250.41 & 319.57 & 372.24 & 269.81 & 297.69 & 442.32 & 402.33 & 390.08 & 348.26 \\
\hline $\mathrm{T}$ & 15.30 & 15.72 & 15.83 & 16.70 & 18.32 & 15.44 & 15.61 & 16.60 & 17.67 \\
\hline $\mathrm{BW}$ & 37.57 & 98.68 & 147.58 & 70.69 & 97.11 & 219.64 & 181.61 & 171.5 & 142.63 \\
\hline GWF & 203.40 & 204.94 & 206.45 & 187.02 & 187.27 & 201.95 & 203.32 & 200.23 & 190.10 \\
\hline GWS & 52.22 & 60.53 & 45.06 & 35.14 & 48.17 & 56.63 & 48.05 & 49.60 & 53.53 \\
\hline
\end{tabular}

P: precipitation (mm/year), T: temperature $\left({ }^{\circ} \mathrm{C}\right)$, BW: blue water $(\mathrm{mm} /$ year),

GWF: green water flow (mm/year), GWS: green water storage (mm/year)

Calculations show that GWF only increases in the near future by the MIROCESM model considering the historical period. The increase of this component is about $0.75-1.49 \%$, while it will be decreased by $8.05 \%$ under different conditions. $\mathrm{P}, \mathrm{BW}$, and GWF were higher during the near future in similar RCPs than those in the far future. However, the T component in similar RCPs shows an inverse result. GWF shows negative and positive trends by moving from the historical to near and far future, respectively. On the other hand, using two GCMs leads to differences between results. The findings of studies by Pandey et al. (2019), Xue et al. (2017), and Su et al. (2016), also support and confirm these results. From the results of Table 6 , it could be deduced that $\mathrm{P}$ will rise up by $7.2-43.4 \%$, BW will increase by 46.9 $82.9 \%$, the T will increase by $0.9-16.5 \%$ in both RCPs and during both future periods (in comparison with historical period), while GWF will increase by $0.8-1.5 \%$ and decrease by $0.7-8.8 \%$. Moreover, GWS tends to increase about $2.4-13.7 \%$ or decrease about $5.3-48.6 \%$ in the future intervals. 
The annual $\mathrm{P}$ in MIROC-ESM under RCP4.5 (RCP8.5) will decrease by $15.6 \%(20 \%)$ in the far-term projection in comparison with that in the near-term projection. This component will decrease for both scenarios approximately by 11.8 and $13.4 \%$ in GFDL-ESM2G, respectively. However, the simulation results of the GFDL-ESM2G model in the near future under RCP4.5 (RCP8.5) is about $38.4 \%(8.1 \%)$ and is about $44.6 \%(17 \%)$ in the far future, which is more than that projected by the MIROC-ESM model. The T component under RCP4.5 and RCP8.5 in MIROC-ESM (GFDL-ESM2G) will increase approximately by 6.2 and $15.7 \%$ (7.5 and $13.2 \%)$ via moving from near-to far-term period. Furthermore, the GFDL-ESM2G under RCP4.5 (RCP8.5) simulated the annual T in the near future by $1.8 \%(1.4 \%)$ and in the far future by $0.6 \%(3.5 \%)$ less than those projected by the MIROC-ESM model, respectively. The annual BW in MIROC-ESM under RCP4.5 (RCP8.5) will decrease by $28.4 \%(34.2 \%)$ in the farterm projection in comparison with that in the near-term projection. This component will decrease for both scenarios approximately by 21.9 and $21.5 \%$ in GFDL-ESM2G, respectively. The amount of BW in GFDL-ESM2G in both future time periods are higher than that of MIROC-ESM. The values of GWF in the near future are higher than in the far future (between 0.9 to $8.7 \%$ under RCP4.5 and between 6.5 to $9.3 \%$ under RCP8.5) in both models and RCPs. The increasing or decreasing of GWS through the MIROC-ESM will be around $6.4 \%(6.6 \%)$ in comparison with GFDL-ESM2G under RCP4.5 (RCP8.5) in the near and will be around $41.1 \%(11.1 \%)$ in the far future intervals, respectively.

Another purpose of the study is to project the conditions of Kardeh and Torogh dam s' sub-basins for the near and far perspectives. In this study, Torogh and Kardeh dams, which are located in the southern and northern part of the KRB with different topography conditions, were selected as the two important dams located in the sub-basins 133 and 52 in order to further investigate the conditions of hydraulic structures in KRB (i.e., dams, which are the most important sources for access to water resources), respectively. The mean annual values of BW (the summation of WYLD (runoff) and DA_RCHG (aquifer discharge)), GWF (ET (evapotranspiration)), and GWS (SW (soil water content)) were extracted from the output.sub file via modeling in SWAT and SWAT-CUP software at different time periods (historical and future), and the results are presented in Table 7.

The GFDL-ESM2G model calculated BW higher than the MIROC-ESM in these two sub-basins in all cases in our study. The mean annual BW increases in both models and periods compared to the historical period under RCP4.5 and 8.5. The highest mean value of BW will occur in the near future, under RCP4.5, simulated by the GFDL-ESM2G in both sub-basins of the dams, while the GWS simulation shows different results. The highest mean annual GWF and GWS in both sub-basins of the dams will happen in the near future under RCP4.5, simulated by the MIROC-ESM. On the other hand, the lowest values of BW, GWF, and GWS will happen in the far future under RCP4.5 by the MIROC-ESM model. More details are represented in Table 7. 
Table 7. Mean annual water resources components in Torogh and Kardeh dams' sub-basins $(\mathrm{mm} /$ year)

\begin{tabular}{|c|c|c|c|c|c|c|c|c|}
\hline & \multirow{3}{*}{\multicolumn{2}{|c|}{$\begin{array}{l}\text { Dams } \\
\text { Water components } \\
\text { Historical period }\end{array}$}} & \multicolumn{3}{|c|}{ Torogh } & \multicolumn{3}{|c|}{ Kardeh } \\
\hline & & & BW & GWF & GWS & BW & GWF & GWS \\
\hline & & & 24.9 & 179.7 & 53.9 & 16.9 & 226.2 & 63.2 \\
\hline \multirow{4}{*}{$\begin{array}{l}\text { Near } \\
\text { future }\end{array}$} & \multirow{2}{*}{$\mathrm{RCP} 4.5$} & $\begin{array}{l}\text { GFDL- } \\
\text { ESM2G }\end{array}$ & 285.2 & 161.9 & 46.4 & 267.2 & 198.1 & 164.2 \\
\hline & & MIROC-ESM & 147.5 & 175.0 & 58.1 & 91.2 & 203.6 & 211.1 \\
\hline & \multirow[t]{2}{*}{ RCP 8.5} & $\begin{array}{l}\text { GFDL- } \\
\text { ESM2G }\end{array}$ & 235.4 & 165.8 & 55.5 & 253.1 & 196.8 & 130.9 \\
\hline & & MIROC-ESM & 220.6 & 173.4 & 51.3 & 153.1 & 197.0 & 185.9 \\
\hline \multirow{4}{*}{$\begin{array}{l}\text { Far } \\
\text { future }\end{array}$} & \multirow[t]{2}{*}{$\mathrm{RCP} 4.5$} & $\begin{array}{l}\text { GFDL- } \\
\text { ESM2G }\end{array}$ & 227.8 & 162.3 & 44.4 & 226.9 & 192.3 & 173.0 \\
\hline & & MIROC-ESM & 108.2 & 153.3 & 41.7 & 65.9 & 175.8 & 112.4 \\
\hline & \multirow[t]{2}{*}{ RCP 8.5} & $\begin{array}{l}\text { GFDL- } \\
\text { ESM2G }\end{array}$ & 193.5 & 153.9 & 46.0 & 180.4 & 179.2 & 155.8 \\
\hline & & MIROC-ESM & 170.9 & 158.1 & 44.0 & 117.2 & 178.0 & 161.0 \\
\hline
\end{tabular}

\section{Summary and conclusions}

Potential use of MIROC-ESM and GFDL-ESM2G models under RCP4.5 and 8.5 in the historical (1995-2011), near (2014-2042), and far (2043-2100) periods to evaluate the status of water resources components (such as BW, GWF, and GWS) due to changes in climatic components (such as P and T) in KRB were simulated via the SWAT model. The SUFI-2 algorithm is applied at a monthly time step in five hydrometric stations to survey sensitivity and uncertainty analysis of the SWAT model. The main summary of the results is illustrated as follows:

1) Sensitivity analysis was done by the regional sensitivity analysis (RSA) method and the Kolmogorov-Smirnov (K-S) test. Results showed that 20 parameters are known as sensitive parameters. The most sensitive parameters for outflow are: ESCO, GW_REVAP, SOL_AWC, and SFTMP, while the parameters of RCHRG_DP, SOL_K, and SMTMP seemed to be less sensitive.

2) The model performance criteria (such as NS, $\mathrm{R}^{2}, \mathrm{P}$, and R-factor) were rather satisfying for the KRB region, and the SWAT model setup is suitable for KRB to evaluate the flows of BW, GWF, and GWS.

3) MIROC-ESM and GFDL-ESM2G models indicated the highest compliance with the observational rainfall data in accordance with the evaluation metrics such as NS (MIROC-ESM=0.95 and GFDL-ESM2G=0.92), PBIAS 
$($ MIROC-ESM $=-2.88$ and GFDL-ESM2G $=-2.93), R^{2}$ (MIROC-ESM=0.97 and GFDL-ESM2G=0.94), and RSR (MIROC-ESM=0.33 and GFDL$\mathrm{ESM} 2 \mathrm{G}=0.37$ ), regarding the lack of information in the study area.

4) BW increases in all future periods and RCPs compared to the historical period due to an increase in precipitation patterns. The amount of $\mathrm{BW}$ in RCP8.5 was higher than in RCP4.5 in MIROC-ESM in the two future periods, but these values were vice versa in GFDL-ESM2G. BW was also higher in the near future than in the far future in both RCPs.

5) GWF were decreased in all future periods and RCPs in comparison with the historical period, except in the near future in both RCPs in MIROC-ESM. The amount of GWF in RCP8.5 is higher than RCP4.5 in both near and far future in MIROC-ESM, but this component was higher in RCP8.5 in GFDLESM2G than in RCP4.5 in the near future and conversely in the far future period. On the other hand, the values of GWF in the near future in both models and RCPs were higher than in the far future.

6) The GWS demonstrated positive and negative trends in different future intervals compared to the historical period. This component was more in RCP4.5 than RCP8.5 in both models and in the near future, and these results are opposite in the far future. The values of GWS in the near future were higher than in the far future in both models in RCP4.5, and these values were more in the far future than in the near future in RCP8.5.

7) The mean annual BW increased in both models and periods under RCP4.5 and 8.5 in the Kardeh and Torogh dam s' sub-basins, in comparison with the historical period. The highest mean annual GWS in both dam's sub-basins will happen in the near future under RCP4.5, simulated by MIROC-ESM. The lowest values of BW and GWF will occur in both sub-basins in MIROCESM and in the far future under RCP4.5.

Finally, it should be noted that the use of different models and scenarios identifies the range of uncertainty forecasts. The existence of differences between results of water components in the CMIP5 model limits the range of uncertainty and enlarges reliability of the projections. In addition, these models might provide decision makers and local authorities with appropriate vision for the near and long perspective condition of the region to adapt and optimize water resources in the KRB with climate change.

A complementry work to this study would be exploring the security of water resources (demand, availability, scarcity, reliability, and vulnerability) based on BW and GW trace by making an application of the mentioned models in this region and similar sub-basins with considering the changes of slope and land-use in the future time periods.

Acknowledgment:The authors would like to thank the Iran National Science Foundation (INSF) for the financial support of this study. The corresponding contract number is 96005746. 


\section{References}

Abbaspour, K.C., Faramarzi, M., Ghasemi, S.S., and Yang, H., 2009: Assessing the impact of climate change on water resources in Iran. Water Resour. Res. 45., 1-16.

https://doi.org/10.1029/2008WR007615

Abbaspour, K.C., 2007: User manual for SWAT-CUP, SWAT calibration and uncertainty analysis programs. Swiss Federal Institute of Aquatic Science and Technology, Eawag, Duebendorf, Switzerland, 93.

Abbaspour, K.C., Yang, J., Maximov, I., Siber, R., Bogner, K., Mieleitner, J., Zobrist, J., and Srinivasan, $R$., 2007: Modelling hydrology and water quality in the pre-alpine/alpine Thur watershed using SWAT. J. Hydrol. 333, 413-430. https://doi.org/10.1016/j.jhydrol.2006.09.014

Afshar, A.A., and Hassanzadeh, Y., 2017: Determination of monthly hydrological erosion severity and runoff in Torogh Dam watershed basin using SWAT and WEPP models. Iranian J.Sci. Technol. Transact. Civil Engineer. 41, 221-228. https://doi.org/10.1007/s40996-017-0056-1

Afshar, A.A., Hasanzadeh, Y., Besalatpour, A.A., and Pourreza-Bilondi, M., 2017: Climate change forecasting in a mountainous data scarce watershed using CMIP5 models under representative concentration pathways. Theor. Appl. Climatol. 129, 683-699.

https://doi.org/10.1007/s00704-016-1908-5

Afshar, A.A., Hassanzadeh, Y., Pourreza-Bilondi, M., and Ahmadi, A., 2018: Analyzing long-term spatial variability of blue and green water footprints in a semi-arid mountainous basin with MIROC-ESM model (case study: Kashafrood River Basin, Iran). Theor. Appl. Climatol. 134, 885-899. https://doi.org/10.1007/s00704-017-2309-0

Arnold, J.G., Moriasi, D.N., Gassman, P.W., Abbaspour, K.C., White, M.J., Srinivasan, R., Santhi, C., Harmel, R.D., Van Griensven, A., Van Liew, M.W., and Kannan, N., 2012: SWAT: Model use, calibration, and validation. Transact. ASABE 55, 1491-1508.

https://doi.org/10.13031/2013.42256

Badou, D.F., Diekkrüger, B., Kapangaziwiri, E., Mbaye, M.L., Yira, Y., Lawin, E.A., Oyerinde, G.T., and Afouda, A., 2018: Modelling blue and green water availability under climate change in the Beninese Basin of the Niger River Basin, West Africa. Hydrol. Process. 32, 2526-2542.

https://doi.org/10.1002/hyp.13153

Besharat, M., Tarinejad, R., and Ramos, H.M., 2015: The effect of water hammer on a confined air pocket towards flow energy storage system. J. Water Supply: Res. Technol.-AQUA 65, 116-126. https://doi.org/10.2166/aqua.2015.081

Chaturvedi, R.K., Joshi, J., Jayaraman, M., Bala, G., and Ravindranath, N.H., 2012: Multi-model climate change projections for India under representative concentration pathways. Current Sci. 103, 791-802. https://www.jstor.org/stable/24088836

Cuceloglu, G., Abbaspour, K.C., and Ozturk, I., 2017: Assessing the Water-Resources Potential of Istanbul by Using a Soil and Water Assessment Tool (SWAT) Hydrological Model. Water, 9(10), 1-18. https://doi.org/10.3390/w9100814

Dadfar, A., Besharat, M., and Ramos, H.M., 2019: Storage ponds application for flood control, hydropower generation and water supply. Int.l Rev. Civil Engineer.(IRECE), 10, 219-226. https://doi.org/10.15866/irece.v10i4.17133

Duan, K., and Mei, Y., 2014: A comparison study of three statistical downscaling methods and their model-averaging ensemble for precipitation downscaling in China. Theor. Appl. Climatol. 116, 707-719. https://doi.org/10.1007/s00704-013-1069-8

Dunne, J.P., John, J.G., Adcroft, A.J., Griffies, S. M., Hallberg, R.W., Shevliakova, E., Stouffer, R.J., Cooke, W., Dunne, K.A., Harrison, M.J., and Krasting, J.P., 2012: GFDL's ESM2 global coupled climate-carbon earth system models. Part I: Physical formulation and baseline simulation characteristics. J. Climate, 25, 6646-6665. https://doi.org/10.1175/JCLI-D-11-00560.1

Dunne, J.P., John, J.G., Shevliakova, E., Stouffer, R.J., Krasting, J.P., Malyshev, S.L., Milly, P.C.D., Sentman, L.T., Adcroft, A.J., Cooke, W., and Dunne, K.A., 2013: GFDL's ESM2 global coupled climate-carbon earth system models. Part II: carbon system formulation and baseline simulation characteristics. J. Climate, 26, 2247-2267. https://doi.org/10.1175/JCLI-D-12-00150.1 
Falkenmark, M., 1995: Coping with water scarcity under rapid population growth. In Conference of SADC ministers, Pretoria, 23, 23-24.

Falkenmark, M., and Rockström, J., 2006: The new blue and green water paradigm: Breaking new ground for water resources planning and management. J. Water Res. Plan. Manage. 132, 129-132. https://doi.org/10.1061/(ASCE)0733-9496(2006)132:3(129)

Faramarzi, M., Abbaspour, K.C., Schulin, R., and Yang, H., 2009: Modelling blue and green water resources availability in Iran. Hydrol. Proc. 23, 486-501. https://doi.org/10.1002/hyp.7160

Faramarzi, M., Abbaspour, K.C., Vaghefi, S.A., Farzaneh, M.R., Zehnder, A.J., Srinivasan, R., and Yang, H., 2013: Modeling impacts of climate change on freshwater availability in Africa. $J$. Hydrol 480, 85-101. https://doi.org/10.1016/j.jhydrol.2012.12.016

Fazeli Farsani, I., Farzaneh, M.R., Besalatpour, A.A., Salehi, M.H., and Faramarzi, M., 2019: Assessment of the impact of climate change on spatiotemporal variability of blue and green water resources under CMIP3 and CMIP5 models in a highly mountainous watershed. Theor.Appl. Climatol. 136, 169-184. https://doi.org/10.1007/s00704-018-2474-9

Freer, J., Beven, K., and Ambroise, B., 1996: Bayesian estimation of uncertainty in runoff prediction and the value of data: An application of the GLUE approach. Water Resour. Res. 32, 2161-2173. https://doi.org/10.1029/95WR03723

Giles, N.A., Babbar-Sebens, M., Srinivasan, R., Ficklin, D.L., and Barnhart, B., 2019: Optimization of linear stream temperature model parameters in the soil and water assessment tool for the continental United States. Ecol. Engineer. 127, 125-134.

https://doi.org/10.1016/j.ecoleng.2018.11.012

Hassanzadeh, Y., Afshar, A.A., Pourreza-Bilondi, M., Memarian, H., and Besalatpour, A.A., 2019: Toward a combined Bayesian frameworks to quantify parameter uncertainty in a large mountainous catchment with high spatial variability. Environ. Monitor. Assess. 191, 23. https://doi.org/10.1007/s10661-018-7145-x

Hijioka, Y., Matsuoka, Y., Nishimoto, H., Masui, T., and Kainuma, M., 2008: Global GHG emission scenarios under GHG concentration stabilization targets. J. Glob. Environ. Engineer. 13, 97-108.

Hoekstra, A.Y., 2017: Water footprint assessment: evolvement of a new research field. Water Resources Management, 31(10), 3061-3081. https://doi.org/10.1007/s11269-017-1618-5

Huang, S., Kumar, R., Flörke, M., Yang, T., Hundecha, Y., Kraft, P., Gao, C., Gelfan, A., Liersch, S., Lobanova, A, and Strauch, M., 2017: Evaluation of an ensemble of regional hydrological models in 12 large-scale river basins worldwide. Climatic Change 141, 381-397.

https://doi.org/10.1007/s10584-016-1841-8

IPCC, 1990: Climate change: the IPCC scientific assessment (1990). Cambridge University Press, London, 410p.

IPCC, 2013: Climate change 2013: the physical science basis: Contribution of working group I to the fifth assessment report of the intergovernmental panel on climate change. (Eds. Stocker TF, Qin D, Plattner GK, Tignor M, Allen SK, Boschung J, Allen SK, Nauels A, Xia Y, Bex V, Midgley BM). Cambridge University Press, Cambridge, UK, 1535p.

Jiang, D., and Tian, Z., 2013: East Asian monsoon change for the 21st century: Results of CMIP3 and CMIP5 models. Chinese Sci. Bull. 58, 1427-1435. https://doi.org/10.1007/s11434-012-5533-0

Lathuillière, M.J., Coe, M.T., and Johnson, M.S., 2016: A review of green-and blue-water resources and their trade-offs for future agricultural production in the Amazon Basin: what could irrigated agriculture mean for Amazonia?. Hydrol. Earth Syst. Sci. 20, 2179-2194. https://doi.org/10.5194/hess-20-2179-2016

Li, B., Liang, Z., He, Y., Hu, L., Zhao, W., and Acharya, K., 2017: Comparison of parameter uncertainty analysis techniques for a TOPMODEL application.Stochast. Environ. Res. Risk Assess. 31, 1045-1059. https://doi.org/10.1007/s00477-016-1319-2

Liu, R., Wang, Q., Xu, F., Men, C., and Guo, L., 2017: Impacts of manure application on SWAT model outputs in the Xiangxi River watershed. J. Hydrol. 555, 479-488. https://doi.org/10.1016/j.jhydrol.2017.10.044

Masud, M.B., McAllister, T., Cordeiro, M.R., and Faramarzi, M., 2018: Modeling future water footprint of barley production in Alberta, Canada: Implications for water use and yields to 2064. Sci. Total Environ. 616-617, 208-222. https://doi.org/10.1016/j.scitotenv.2017.11.004 
McKay, M.D., Beckman, R.J., and Conover, W.J., 1979: Comparison of three methods for selecting values of input variables in the analysis of output from a computer code. Technometrics 21, 239-245. https://doi.org/10.1080/00401706.1979.10489755

Mekonnen, M.M., and Hoekstra, A.Y., 2016: Four billion people facing severe water scarcity. Sci. Advances 2(2), 1-6. https://doi.org/10.1126/sciadv.1500323

Moriasi, D.N., Arnold, J.G., Van Liew, M.W., Bingner, R.L., Harmel, R.D., and Veith, T.L., 2007: Model evaluation guidelines for systematic quantification of accuracy in watershed simulations. Transact. ASABE, 50, 885-900. https://doi.org/10.13031/2013.23153

Moss, R.H., Edmonds, J.A., Hibbard, K.A., Manning, M.R., Rose, S.K., Van Vuuren, D.P., Carter, T.R., Emori, S., Kainumam M., Kram, T., and Meehl, G.A., 2010: The next generation of scenarios for climate change research and assessment. Nature 463(7282), 747-756. https://doi.org/10.1038/nature08823

Nash, J.E., and Sutcliffe, J.V., 1970: River flow forecasting through conceptual models part I-A discussion of principles. J. Hydrol. 10, 282-290. https://doi.org/10.1016/0022-1694(70)90255-6

Nossent, J., and Bauwens, $W$., 2012: Multi-variable sensitivity and identifiability analysis for a complex environmental model in view of integrated water quantity and water quality modeling. Water Sci. Technology, 65(3), 539-549. https://doi.org/10.2166/wst.2012.884

Nozawa, T., Nagashima, T., Ogura, T., Yokohata, T., Okada, N., and Shiogama, H., 2007: Climate change simulations with a coupled ocean-atmosphere GCM called the model for interdisciplinary research on climate: MIROC. CGER's Supercomputer Monograph Report, 12, 73.

Pachauri, R.K., Allen, M.R., Barros, V.R., Broome, J., Cramer, W., Christ, R., Church, J.A.,Clarke, L., Dahe, Q., Dasgupta, P., Dubash, N.K., Edenhofer, O., Elgizouli, I., Field, C.B., Forster, P., Friedlingstein, P., Fuglestvedt, J., Gomez-Echeverri, L., Hallegatte, S., Hegerl, G., Howden, M., Jiang, K., Jimenez Cisneroz, B., Kattsov, V.,Lee, H., Mach, K.J., Marotzke, J., Mastrandrea, M.D., Meyer, L., Minx, J., Mulugetta, Y., O'Brien, K.,Oppenheimer, M., Pereira, J.J., Pichs-Madruga, R., Plattner, G.K., Pörtner, H.O., Power, S.B.,Preston, B., Ravindranath, N.H., Reisinger, A., Riahi, K., Rusticucci, M., Scholes, R., Seyboth, K., Sokona, Y., Stavins, R., Stocker, T.F., Tschakert, P., van Vuuren, D., and van Ypserle, J.P., 2014: Climate Change 2014: Synthesis Report. Contribution of Working Groups I, II and III to the Fifth Assessment Report of the Intergovernmental Panel on Climate Change/R. (eds. Pachauri and Meyer), Geneva, Switzerland, IPCC, 151 p., ISBN: 978-92-9169-143-2.

Pandey, B.K., Khare, D., Kawasaki, A., and Mishra, P.K., 2019: Climate change impact assessment on blue and green water by coupling of representative CMIP5 climate models with physical based hydrological model. Water Res. Manage. 33, 141-158. https://doi.org/10.1007/s11269-018-2093-3

Pereira, L.S., Cordery, I., and Iacovides, I., 2009: Coping with water scarcity: Addressing the challenges. Springer Science and Business Media. https://doi.org/10.1007/978-1-4020-9579-5

Rahimpour, M., Tajbakhsh, M., Memarian, H., and Aghakhani Afshar, A., 2020: Impact assessment of climate change on hydro-climatic conditions of arid and semi-arid watersheds (case study: ZoshkAbardeh watershed, Iran). J. Water Climate Change. https://doi.org/10.2166/wcc.2020.224

Riahi, K., Rao, S., Krey, V., Cho, C., Chirkov, V., Fischer, G., Kindermann, G., Nakicenovic, N., and Rafaj, $P$., 2011: RCP 8.5 - A scenario of comparatively high greenhouse gas emissions. Climatic Change 109, 33-57. https://doi.org/10.1007/s10584-011-0149-y

Rodrigues, D.B., Gupta, H.V., and Mendiondo, E.M., 2014: A blue/green water-based accounting framework for assessment of water security. Water Resour. Res. 50, 7187-7205.

https://doi.org/10.1002/2013WR014274

Salzmann, M., Weser, H., and Cherian, R., 2014: Robust response of Asian summer monsoon to anthropogenic aerosols in CMIP5 models. J. Geophys. Res.: Atmospheres, 119, 11321-11337. https://doi.org/10.1002/2014JD021783

Samuels, R., Hochman, A., Baharad, A., Givati, A., Levi, Y., Yosef, Y., Saaroni, H., Ziv, B., Harpaz, T., and Alpert, P., 2018: Evaluation and projection of extreme precipitation indices in the Eastern Mediterranean based on CMIP5 multi-model ensemble. Int. J. Climatol. 38, 2280-2297. https://doi.org/10.1002/joc.5334

Schyns, J.F., Hoekstra, A.Y., Booij, M.J., Hogeboom, R.J., and Mekonnen, M.M., 2019: Limits to the world's green water resources for food, feed, fiber, timber, and bioenergy. Proc. Nat. Acad. Sci. 116, 4893-4898. https://doi.org/10.1073/pnas.1817380116 
Schyns, J.F., Hoekstra, A.Y., and Booij, M.J., 2015: Review and classification of indicators of green water availability and scarcity. Hydrology and Earth Syst. Sci. 19, 4581-4608. https://doi.org/10.5194/hess-19-4581-2015

Shivhare, N., Dikshit, P.K.S., and Dwivedi, S.B., 2018: A Comparison of SWAT Model Calibration Techniques for Hydrological Modeling in the Ganga River Watershed. Engineering, 4, 643-652. https://doi.org/10.1016/j.eng.2018.08.012

Shrestha, N.K., Du, X., and Wang, J., 2017: Assessing climate change impacts on fresh water resources of the Athabasca River Basin, Canada. Sci. Total Environ. 601, 425-440. https://doi.org/10.1016/j.scitotenv.2017.05.013

Smith, S.J., and Wigley, T.M.L., 2006: Multi-gas forcing stabilization with the MiniCAM. Multigreenhouse gas mitigation and climate policy. Energy J. 27, 373-391. https://doi.org/10.5547/ISSN0195-6574-EJ-VolSI2006-NoSI3-19

Sobol, I.M., 2001: Global sensitivity indices for nonlinear mathematical models and their Monte Carlo estimates. Math. Comput. Simulation, 55, 271-280. https://doi.org/10.1016/S0378-4754(00)00270-6

Su, F., Zhang, L., Ou, T., Chen, D., Yao, T., Tong, K., and Qi, Y., 2016: Hydrological response to future climate changes for the major upstream river basins in the Tibetan Plateau. Glob. Planet. Change 136, 82-95. https://doi.org/10.1016/j.gloplacha.2015.10.012

Sylla, M.B., Giorgi, F., Pal, J.S., Gibba, P., Kebe, I., and Nikiema, M., 2015: Projected changes in the annual cycle of high-intensity precipitation events over West Africa for the late twenty-first century. J. Climate 28, 6475-6488. https://doi.org/10.1175/JCLI-D-14-00854.1. https://doi.org/10.1175/JCLI-D-14-00854.1

Taylor, K.E., Stouffer, R.J., and Meehl, G.A., 2012: An overview of CMIP5 and the experiment design, Bull. Amer. Meteorol. Soc. 93, 485-498. https://doi.org/10.1175/BAMS-D-11-00094.1

Uniyal, B., Jha, M.K., and Verma, A.K., 2015: Parameter identification and uncertainty analysis for simulating streamflow in a river basin of Eastern India. Hydrol.Proc., 29, 3744-3766. https://doi.org/10.1002/hyp.10446

Van Griensven, A.V., Meixner, T., Grunwald, S., Bishop, T., Diluzio, M., and Srinivasan, R., 2006: A global sensitivity analysis tool for the parameters of multi-variable catchment models. $J$. Hydrology, 324, 10-23. https://doi.org/10.1016/j.jhydrol.2005.09.008

Van Vuuren, D.P., Edmonds, J., Kainuma, M., Riahi, K., Thomson, A., Hibbard, K., Hurtt, G.C., Kram, T., Krey, V., Lamarque, J.F., and Masui, T., 2011a: The representative concentration pathways: an overview. Climatic Change, 109, 5-31. https://doi.org/10.1007/s10584-011-0148-z

Van Vuuren, D.P., Stehfest, E., den Elzen, M.G., Kram, T., van Vliet, J., Deetman, S., Isaac, M., Goldewijk, K.K., Hof, A., Beltran, A.M., and Oostenrijk, R., 2011b: RCP2. 6: exploring the possibility to keep global mean temperature increase below 2 C. Climatic Change, 109, 95. https://doi.org/10.1007/s10584-011-0152-3

Veettil, A.V., and Mishra, A.K., 2016: Water security assessment using blue and green water footprint concepts. J. Hydrol. 542, 589-602. https://doi.org/10.1016/j.jhydrol.2016.09.032

Watanabe, S., Hajima, T., Sudo, K., Nagashima, T., Takemura, T., Okajima, H., Nozawa, T., Kawase, H., Abe, M., Yokohata, T., and Ise, T., 2011: MIROC-ESM: model description and basic results of CMIP5-20c3m experiments. Geoscie. Model Develop. Discuss. 4, 1063-1128. https://doi.org/10.5194/gmdd-4-1063-2011

Woldemeskel, F.M., Sharma, A., Sivakumar, B., and Mehrotra, R., 2016: Quantification of precipitation and temperature uncertainties simulated by CMIP3 and CMIP5 models. J. Geophys. Res.: Atmospheres, 121, 3-17. https://doi.org/10.1002/2015JD023719

Xue, L., Zhu, B., Yang, C., Wei, G., Meng, X., Long, A., and Yang, G., 2017: Study on the characteristics of future precipitation in response to external changes over arid and humid basins. Sci. Rep. 7 , 1-13. https://doi.org/10.1038/s41598-017-15511-5

Zadeh, F.K., Nossent, J., Sarrazin, F., Pianosi, F., van Griensven, A., Wagener, T., and Bauwens, W., 2017: Comparison of variance-based and moment-independent global sensitivity analysis approaches by application to the SWAT model. Environ. Modell. Software 91, 210-222. https://doi.org/10.1016/j.envsoft.2017.02.001 
Zang, C.F., Liu, J., Velde, M., and Kraxner, F., 2012: Assessment of spatial and temporal patterns of green and blue water flows under natural conditions in inland river basins in Northwest China. Hydrology and Earth Syst. Sci. 16, 2859-2870. https://doi.org/10.5194/hess-16-2859-2012

Zhu, H., Li, Y., Liu, Z., Shi, X., Fu, B., and Xing, Z., 2015: Using SWAT to simulate streamflow in Huifa River basin with ground and Fengyun precipitation data. J. Hydroinformatics 17, 834-844. https://doi.org/10.2166/hydro.2015.104

Zuo, D., Xu, Z., Peng, D., Song, J., Cheng, L., Wei, S., Abbaspour, K.C., and Yang, H., 2015: Simulating spatiotemporal variability of blue and green water resources availability with uncertainty analysis. Hydrol. Proc. 29, 1942-1955. https://doi.org/10.1002/hyp.10307 